\title{
Labour Segregation and Immigrant and Native-born Wage Distributions in Spain: An Analysis Using Matched Employer-Employee Data*
}

\author{
Hipólito Simón \\ Universidad de Alicante-Instituto de Economía Internacional \\ Esteban Sanromá \\ IEB-Universidad de Barcelona \\ Raúl Ramos \\ AQR-IREA-Universidad de Barcelona
}

\begin{abstract}
This article carries out an empirical examination of the origin of the differences between immigrant and native-born wage structures in the Spanish labour market. Especial attention is given in the analysis to the role played by occupational and workplace segregation of immigrants. Legal immigrants from developing countries exhibit lower mean wages and a more compressed wage structure than native-born workers. By contrast, immigrants from developed countries display higher mean wages and a more dispersed wage structure. The main empirical finding is that the disparities in the wage distributions for the native-born and both groups of immigrants are largely explained by their different observed characteristics, with a particularly important influence in this context of workplace and, particularly, occupational segregation.
\end{abstract}

Keywords: Wage differentials between native-born and immigrant workers; labour market segregation; immigrant workers.

JEL Codes: J15, J24, J30, J61.

\footnotetext{
* Hipólito Simón, Esteban Sanromá and Raúl Ramos wish to thank the support received from the Ministerio de Fomento and the Ministerio de Educación y Ciencia through the projects T 75/2006 (Plan Nacional de Investigación, Desarrollo e Innovación Cientifica), SEJ2004-05860/ECON, and SEJ2005-04348/ECON, respectively. A previous version of this paper was published as an IVIE Working Paper (WP-EC 2007-03).
} 


\section{Introduction}

The relative situation of immigrants in the labour market of the host country has played a central role in the numerous studies carried out in recent decades on the subject of international migration and its consequences (Borjas, 1999; Lalonde and Topel, 1997 and Card, 2004). This literature has placed especial attention on the wages of immigrants relative to native-born workers and its key empirical findings are, firstly, that immigrants typically face a significant wage gap and, secondly, that the gap tends to diminish the longer they remain in their host country (Chiswick, 1978 and Borjas, 1994, 1999 for the US; Chiswick, Lee and Miller, 2005a for Australia; Friedberg, 2000 for Israel; Lam and Liu, 2002 for Hong Kong and Baker and Benjamin, 1994 for Canada).

Building on these studies, this article aims to examine differences between legal immigrants and native-born wage structures in the Spanish labour market and their origin. A growing number of studies in recent years have addressed the phenomenon of immigration in Spain and promoted greater understanding of it and its impact (for a general view, see Izquierdo and Jimeno, 2005 and Consejo Económico y Social, 2004). These studies, however, have not addressed the relative wages of immigrants. Nonetheless, an empirical examination of the magnitude and the causes of the differences between native-born and immigrant wage distributions is undoubtedly of great interest, as it allows for a more complete understanding of the relative situation of immigrants in the Spanish labour market and provides useful evidence from an economic policy standpoint on the factors that may influence in the reduction on the wage gap between native-born and immigrant workers.

Our empirical analysis takes especial interest in the extent to which wage structure differences arise between native-born and immigrant workers due to the segregation of immigrants into low-wage occupations and workplaces. Such segregation may stem from discriminatory practices, as predicted by standard statistical discrimination models (Phelps, 1972) or taste-based discrimination models à la Becker (1957). In addition, given the robust evidence that supports the existence of significant interracial wage differentials (Altonji and Blank, 1999), this is a more plausible phenomenon when the ethnicities of immigrants actually differ from those of native-born workers. However, it must be considered that immigrant segregation, and more generally wage differences, can also be the result of imperfect transferability of human capital acquired by immigrants in their home countries (Friedberg, 2000).

Addressing occupational segregation, international empirical evidence shows that immigrants are typically segregated in every economy into occupations with terms and conditions that are worse relative to native-born workers (Chiswick, Lee and Miller, 2005b; Jasso and Rosenzweig, 1988; Bauer and Zimmerman, 1999; Weiss et al., 2003, and Constant and Massey, 
2003). For Spain in particular, the findings of Amuedo-Dorantes and De la Rica (2007) confirm that immigrants are segregated into low-wage occupations (with the only exception of immigrants from the EU-15 countries). Yet, given the scarcity of international empirical studies which quantify the relative importance that occupational segregation plays in the explanation of wage gaps between native-born and immigrant workers, our empirical knowledge of the phenomenon is rather imperfect. The main exception in this context is Liu et al. (2004), whose findings interestingly suggest that segregation into low-wage occupations is an outstanding factor in explaining native-born/immigrant average wage gaps.

The use of matched employer-employee microdata in our empirical analysis permits us to examine the influence of both occupational and workplace segregation on the relative wages of immigrants. Segregation into workplaces that pay lower wages to individuals with otherwise similar observed characteristics is actually an important reason of the lower wages earned in practice by women (see, for example, Amuedo-Dorantes and De la Rica, 2006 and Palacio and Simón, 2006 for Spain) and certain ethnic minorities, such as African Americans and Hispanics (Bayard et al., 1999 and Hellerstein and Neumark, 2005 for the US). Nevertheless, as far as we know, there is no existing evidence at an international level regarding the impact of firm segregation on immigrant wages. Hence, the purpose of this research is to contribute toward filling this gap in the literature. Yet, not only the extent of workplace segregation of immigrants, but also which are the specific attributes of the firms where immigrant segregation occurs are relevant concerns in this context. This research therefore looks at the impact on immigrant wages of those firm characteristics more extensively addressed in the literature but, in particular, at that of two attributes related to a firm's workforce composition, namely the proportion of immigrants and the average level of qualifications. As regards the first attribute, the evidence that a relatively high proportion of either women or racial minorities in a firm depresses the relative wages of all workers in that firm (Bayard et al., 2003 and Hirsch and Macpherson, 2004) leads to the question: is the same effect also to be found in Spain in the case of immigrant workers? Concerning the second attribute, an additional question builds on the fact that the average human capital endowment of a firm's workforce affects the individual wages of all its workers, due to human capital externalities, such as productive complementarities and knowledge diffusion (Battu et al., 2003 and Alcalá and Hernández, 2006), namely if the relative wages of immigrants are affected by a greater presence in firms typified by poorly qualified workforces.

The empirical strategy is based on the use of two different methodologies in order to decompose differences between native-born and immigrant workers in both average wage gaps and the entire wage distributions. On that account, the first part of the analysis carries out an examination of the root cause of the differences in average wages, drawing on the use of an extension of the Oaxaca-Blinder technique, which has been adapted for its use with matched 
microdata. This initial enquiry is of interest as it focuses on representative individuals and is, thus, based on a moment of the distribution which is representative of the aggregated behaviour of each of the groups in question. However, the results obtained from comparing the relative wages of native-born and immigrant workers may depend significantly on methodological choices, such as which specific point of the wage structure is used in the comparison (Yuengert, 1994). For this reason, the second part of the empirical analysis consists of a distributional approach. In particular, the methodology put forward by Juhn et al. (1993) is employed in order to analyse the explanatory factors for the overall differences in the wage distributions for native-born and immigrant workers. This technique is based on the estimation of hypothetical wage distributions and its use permits to obtain complementary evidence regarding, inter alia, the extent to which the native-born/immigrant wage gap and its determinants vary throughout the wage distribution and if there are significant differences in these groups' wage dispersion and the causes for that. It is also important to note that, except for some notable exceptions such as Butcher and DiNardo (2002) and Wilkins (2003), this sort of distributional analysis of the differences in the wage structures of immigrants and the native-born is relatively uncommon in the economic literature.

An additional noteworthy point to be stressed is that the empirical analysis has been undertaken disaggregately by gender and by place of origin of immigrants, distinguishing whether the home country is developed or developing. The potential influence of geographic factors on immigrant wages stems from the fact that the degree of human capital transferability depends not only on individual qualifications but also on cultural, institutional and labour market similarities between home and host countries (Chiswick, 1978). Another potential source of this influence lies in the heterogeneity of the self-selection process undergone by immigrants, as they may originate in differing segments of the ability distribution across countries (Borjas, 1987). In turn, there is abundant empirical evidence that corroborates that immigrants' relative wage levels vary significantly as a function of gender and place of origin (Borjas, 1987, 1994 and Adsera and Chiswick, 2007) and, in particular, that immigrants from developing countries experience higher wage gaps and less wage convergence than those from developed countries (Borjas, 1987). This overall evidence supports our methodological decision to differentiate between different types of immigrants. A specific focus in this study, therefore, is to determine the extent to which wage structures for legal immigrants in the Spanish labour market differ depending on their gender and place of origin, as well as the potential effect of the relative extent of labour market segregation on this phenomenon.

Following this introduction, the second section of the article describes the dataset used and presents descriptive evidence concerning average wages and the main features of the wage structures for native-born and legal immigrant workers. The third section sets out in detail the methodology that has been employed. The fourth section then develops the empirical analysis in 
two stages. Firstly, the explanatory factors for the gaps in average wage levels are examined, adapting the traditional Oaxaca-Blinder wage decomposition methodology for its use with the matched employer-employee microdata from the Encuesta de Estructura Salarial. Secondly, the comparative analysis is extended to the entire wage distribution drawing on the use of the Juhn et al. (1993) technique. Finally, the last section states our conclusions.

\section{Data and Descriptive Evidence}

\subsection{The Encuesta de Estructura Salarial 2002}

The microdata used in the study are drawn from the Spanish Encuesta de Estructura Salarial for 2002 (hereafter EES). This survey was carried out by the Spanish National Statistics Office (Instituto Nacional de Estadística) and constitutes the Spanish sample of the European Structure of Earnings Survey (SES), a 4-yearly survey conducted in member states of the European Union according to a standard methodology. The Spanish EES is a national representative survey directed at firms and covers establishments employing at least ten workers and whose economic activities fall within divisions 10 to 93 of the detailed Nomenclature of Economic Activities in the European Union, NACE. Therefore, non-covered sectors include agriculture and fisheries, domestic service, and public administration.

The EES sample is implemented in two stages. Firstly, establishments are sampled at random from the Social Security General Register of Payments records, which are stratified by economic activity, the size of local unit and region. Secondly, employees within these establishments are randomly selected. The number of observations per establishment depends on its size, from an average of 5 workers interviewed in establishments with 10-20 employees, up to 25 workers in establishments with more than 200 employees. A prominent feature of the ESES is, therefore, that it consists of matched employer-employee data with several observations at each establishment.

The EES collects comprehensive information, provided by the management of the establishments, on the level and structure of remuneration of employees; workers' demographic and job characteristics (in particular, nationality, sex, age, level of education, tenure in the firm, occupation, type of contract, supervision tasks indicators and full-time/part-time indicators) along with detailed information for each respondent's establishment (industry, size, region and type of collective agreement) (see Table A.1. of the appendix). Additional features of firm's labour force composition have been derived from the observations of each establishment in the sample (namely, the female and immigrant share and the average years of education, seniority and experience in the firm's workforce) as is quite usual in empirical analysis (see, for instance, Amuedo-Dorantes and De la Rica, 2006 and Alcalá and Hernández, 2006). Yet, given the nature of the sampling of the EES, these are rough measures of the corresponding counterparts in the 
stock of workers of each firm. This room for measurement error in firm attributes computed from the information in the sample must be taken into account in order to interpret the results. Yet, we expect these errors to be small due to the high response rate of firms in the sample: the response rate is $94.88 \%$ and the information provided by firms is related to the $93.94 \%$ of total workers and response rates by region and sector show a low variability. In the same vein, the distribution of the relative shares of men/women and native-born/immigrant workers at the sectoral level is quite similar in our sample and in the Social Security records ${ }^{1}$.

The wage measure is the logarithm of the gross hourly wage, computed as the annual gross earnings in euros divided by the number of hours worked in the year. Gross earnings cover all payments different from overtime pay paid by the employer before deductions for tax and employee social security contributions.

Firms with less than two observations have been excluded of the sample so as to permit an accurate identification of fixed effects by firm in the econometric estimations. Also excluded are those observations lacking information for the main variables of interest or corresponding to workers under 16 or over 65 years of age. The final sample contains 126,367 observations in 14,177 establishments (that is, there are on average 8.91 workers per firm in the dataset). In accordance with the literature, this investigation defines immigrant as a worker whose nationality is not Spanish. This requirement is met by 4,237 individuals, or $3.35 \%$ of the total sample. Of these, 996 come from developed countries (EU-15, North America and Oceania) and 3,241 come from developing countries (the remaining geographic areas).

Table A.1 in the Appendix reports descriptive statistics of native-born employees and legal immigrants by sex and origin. By and large, significant differences in the relative qualifications and other observed characteristics of these groups are to be found. For instance, a greater portion of immigrants from developing countries are male $(73.1 \%)$ than are Spanish workers $(63.8 \%)$. They also have lower educational levels (2.5 schooling years less than natives on average) and less actual potential experience (1.7 years less) and seniority (6.4 years less). ${ }^{2}$ They also engage in higher levels of temporary (60.9\% versus $26.4 \%$ for natives) and part-time work $(12.2 \%$ and $10.5 \%)$ and carry out supervisory tasks to a lesser extent $(11.6 \%$ for immigrants from developing countries and $25.9 \%$ for natives). Moreover, they are especially concentrated in regions characterised by higher employment and wages (Madrid and Catalonia), but working in smaller firms $(27.3 \%$ in firms with less than 20 employees and $20.2 \%$ for natives). Likewise, immigrants from developed countries also exhibit relatively smaller endowments of seniority (4.1 years less) and potential experience (2.5 years), and higher levels of temporary and part-time

\footnotetext{
${ }^{1}$ The results are available from the authors on request.

${ }^{2}$ Potential experience is measured as current age minus age on first entering the labour market after leaving full-time schooling.
} 
work. However, unlike the first group, these immigrants have higher educational levels $(0,9$ more years of schooling) and carry out supervisory tasks to a greater extent than native-born workers (34\% and $25.9 \%$ for natives). Turning back to immigrants from developing countries, it can be seen from analysing the attributes of firms that they tend to work in firms whose workforces exhibit lower levels of education, seniority and experience. At the same time, and relative to native-born workers, all immigrants, irrespective of origin, tend to work in firms with a higher presence of immigrants. Overall, this evidence reveals that there are major differences in characteristics between immigrants and native-born workers, but also between immigrants from developing countries and from developed countries. Hence, this preliminary analysis of the data confirms the interest of analysing in a separate way these two groups of immigrants.

It must be stressed that there are some noteworthy shortcomings of the EES that could potentially affect our analysis. First, as the survey is addressed to firms, it does not include information about workers in the black economy and, as a result, the analysis will be limited to workers in a legal situation. Second, the EES does not cover the whole economy, as firms with fewer than 10 workers are not considered in the survey, and neither it includes certain segments of the labour market (in particular primary sector, domestic service, and public administration). This circumstance gives rise to a slight underrepresentation of immigrants in the sample (and also of women and young workers in both groups) ${ }^{3}$. However, some additional evidence suggests that the wage gap between native-born workers and immigrants is not substantially greater in the segments of the labour market not covered by the EES. Thus, according to the data of the Conditions of Life Survey (Encuesta de Condiciones de Vida) of 2005, a survey to families with a complete coverage of the economy, immigrants from European countries outside the European Union earn higher wages relative to Spaniards, with a gap of 3.3\% (this percentage is $4.4 \%$ in the EES), whereas those coming from countries outside Europe earn lower wages, with a gap of $29.9 \%(26.7 \%$ in the EES). This evidence suggests that the EES tends in general to underestimate, but not in a severe manner, the wage gap between native-born workers and immigrants, which must be considered in order to interpret the results of the empirical analysis.

Nevertheless, in spite of these shortcomings, the use of the EES to analyse the origin of the differences between immigrant and native-born wage structures in the Spanish labour market is highly recommended. On the one hand, it contains a higher number of observations and richer information on workers' demographic, job and firm characteristics than other databases (such as the European Community Household Panel or the Encuesta de Condiciones de Vida). Yet, the foremost reason is that this survey is the only dataset available currently that provides matched employer-employee data with several observations at each establishment for the Spanish labour

\footnotetext{
${ }^{3}$ Further details can be found in Simón et al. (2007).
} 
market. Such matched data uniquely afford the possibility of appropriately weighing up the influence of factors related to labour demand when analysing the wage-setting process (about the role of matched employer-employee datasets in advancing understanding of labour markets see Abowd and Kramarz, 1999 and Haltiwanger et al., 1999). Therefore, these kind of data have a main advantage for the purpose of decomposing wage differentials, namely that they permit to examine the relative contribution of within- and between-workplace wage differentials, so that the effect of firm-level segregation can be taken into account as an additional source of wage differentiation between groups of workers. For that reason, they have been extensively used in the recent past in order to examine the origin in the Spanish labour market of the wage gaps by sex (Amuedo-Dorantes and De la Rica, 2006 and Palacio and Simón, 2006); type of contract (De la Rica, 2004 and Davia and Hernanz, 2004) and full-time/part-time workers (Pagán, 2007). Thus, in the context of this research these data allow to analyse if wage differences between native-born and immigrant workers are related to the segregation of immigrants in different types of firms. This is a subject where, as pointed in the introduction, no previous empirical international evidence is available at present.

\subsection{Descriptive Evidence}

In this section, descriptive evidence about wage differentials between native-born and legal immigrant workers is shown. Figure 1 displays separate estimations of the kernel density functions of the hourly wage for these two groups. The left-hand panel displays density functions estimated for men and women jointly, and the central and right-hand panels break out the density functions for these two groups separately. Firstly, the joint analysis for men and women attests to significant differences between native-born and immigrant wage structures. It also highlights substantial differences between the two groups of immigrants themselves. (The KolmogorovSmirnov test values formally confirm statistically significant differences when comparing any two of the three distributions in question.) More specifically, the wage distribution of immigrants from developed countries is shifted farther to the right and shows a greater degree of dispersion, whereas the wage distribution of immigrants from developing countries is shifted relatively farther to the left and shows less dispersion. The same comparative pattern is repeated for both men and women. However, the density function estimations seem to suggest that nativeborn/immigrant wage structure differences do not coincide systematically for both sexes.

Additional descriptive evidence confirms that there are significant differences in average pay and wage dispersion for native-born and immigrant workers (Table 1). Hence, average hourly wage for immigrants from developed countries exceeds average wage for Spanish workers by $0.149 \log$ points (or 16.1 percentage points). ${ }^{4}$ On the other hand, average wage for immigrants

\footnotetext{
${ }^{4}$ The percentage difference is calculated as $\left(\mathrm{e}^{\mathrm{P}}-1\right) \mathrm{x} 100$, where $P$ is the difference in log points.
} 
from developing countries is lower by $0.256 \log$ points (29.2 percentage points). Similarly, the values for a wide range of inequality indices are systematically higher for the first immigrant group than for Spanish workers. These values are higher, in turn, for Spanish workers than for immigrants from developing countries. This confirms that the wage structures for these groups show rather different degrees of dispersion. ${ }^{5}$ Elaborating on this question, the Lorenz curves for the three groups' wages (available from the authors upon request) confirm that the wages of immigrants from developed countries Lorenz-dominate the wages of Spanish workers and theirs, in turn, Lorenz-dominate the wages of immigrants from developing countries.

The descriptive evidence in Table 1 shows as well that average hourly wage is higher for immigrants from developed countries than it is for Spanish workers both for men and for women (although the gap is notably smaller for men). It is also observed that wage dispersion is comparatively more pronounced in this immigrant group both for men and women than it is for Spanish workers. In contrast, immigrants from developing countries show relatively lower average wages and less wage dispersion for both sexes. Yet, interestingly, this third group is the only one that exhibits larger wage disparities among women than among men.

Summing up, the descriptive evidence conclusively shows that native-born and immigrant wage structures are far from homogeneous in the Spanish labour market. Significant differences appear both in average wage levels and in the degree of wage differentiation between the two groups. In addition, significant disparities can be seen between immigrants from developing and developed countries and, within the two immigrant groups, between men and women. This underlines the value of carrying out an analysis differentiated according to these characteristics. Consequently, the rest of the article examines the source of these wage structure differences between native-born and legal immigrants, starting with the decomposition of average wage differentials, followed by a distributional analysis. First, however, the methodology used in the empirical analysis is described in the third section.

\section{Methodology}

\subsection{Decomposition of average wage differentials: the Oaxaca-Blinder methodology with matched microdata}

The methodology used in the empirical analysis to decompose native-born/immigrant average wage differentials is an extension of the standard Oaxaca-Blinder approach (Oaxaca, 1973; Blinder, 1973). It departs from the estimation of a wage function as follows: ${ }^{6}$

$$
w_{i j}=X_{i} \beta+\lambda_{j}+\varepsilon_{i j}
$$

\footnotetext{
5 The calculation of wage dispersion indices assumes that the observations in the sample are independent and identically distributed. When the calculation of the indices is corrected by the inclusion probability of each observation in the sample, the results are very similar. It should be pointed that although the EES uses a complex design, involving two-stage stratified sampling, this does not affect the estimation of the dispersion values.

${ }^{6}$ The technique used coincides with the methodology proposed by Gartner and Stephan (2004) as an extension of the technique used by Blau and Kahn (1997).
} 
where $w_{i j}$ corresponds to the gross hourly wage for worker $i$ in firm $j$; $X_{i}$ is a vector capturing observed individual and job characteristics, along with a constant term; $\beta$ is a parameter vector; $\lambda_{j}$ is an invariant error term for all individuals within firm $j$; and $\varepsilon_{i j}$ is a random error term.

The vector $X_{i}$ includes individual characteristics -some of which proxy human capital and, consequently, worker productivity-, along with job features. Specifically, the controls include an individual's gender indicator; the level of educational attainment (broken into ten different degrees and diplomas); years of potential experience in the labour market and its quadratic form; seniority and its quadratic form; contract type (distinguishing between permanent or fixed-term) and whether the working day is full-time or part-time. Furthermore, in order to capture the effects of horizontal and vertical job segregation on wages, a set of dummies for occupation (57) and a dummy reflecting whether an individual performs supervisory tasks have in turn been included.

As pointed earlier, the effects $\lambda_{j}$ are common to all individuals in a given firm and they can be identified due to the availability in the microdata of several observations in each firm. The Hausman test indicates that these effects are significantly correlated in the EES sample with the individual and job characteristics in vector $X_{i}$. As a result they have been estimated as fixed effects.

The estimation by fixed effects of equation (1) is equivalent to the use of ordinary least squares with the inclusion of a set of firm dummies. ${ }^{7}$ According to the properties of the ordinary least squares estimator, the average wage of a given group can be expressed after the estimation of equation (1) as follows:

$$
\bar{w}_{A}=\bar{X}_{A} \hat{\beta}+\eta \bar{\gamma}_{A}+\sigma \bar{\theta}_{A}
$$

where $\bar{w}_{A}$ is the average wage of group A (i.e. native-born or immigrant workers); $\bar{X}_{A}$ are the respective group's average characteristics; $\hat{\beta}$ is the vector of the parameters estimated from equation (1); $\eta$ is the sample-wide standard deviation for fixed effects by firm; $\bar{\gamma}_{A}$ is the group's standardised average fixed effect by firm; $\sigma$ is the standard deviation for the sample's wage residuals; and $\bar{\theta}_{A}$ is the group's standardised average wage residual.

When carrying out wage decompositions, it is a quite common methodological decision in the economic literature using as a reference the wage structure estimated separately for the

\footnotetext{
7 Wage decomposition methodologies, when carried out in detail, give rise to problems of identification. Such problems occur because the choice of a specific reference in each group of dummies included in the explanatory variables, so as to avoid the effects of perfect multicollinearity, affects the detailed decomposition findings (Oaxaca and Ransom, 1999). With the aim of accurately estimating the real contribution of each variable, the problems of identification have been corrected and normalised adopting the approach taken by Gardeazábal and Ugidos (2004). Therefore, restricted least squares under the constraint that the sum of the coefficients of each set of dummies equals zero have been employed in the estimation of wage function (1).
} 
majority group (for example, when addressing the gender wage gap, using men as the reference group). This choice rests on the assumption that in a non-discriminatory context this wage structure would correspond to the minority group as well. Alternatively, pooling the wage structures for both groups allows use of all the available information to estimate wage returns. The joint wage structure also constitutes a more natural approximation to the labour market's non-discriminatory wage structure than just adopting the structure of the main group or using other alternatives such as the wage structure of the minority group or a linear combination of the structures of both groups (Oaxaca and Ransom, 1994 and Neumark, 1988). Therefore, equation (1) has been estimated for the pool of native-born and immigrant workers.

Using the pooled wage structure as a reference for decomposition, the average hourly wage gap between the two groups can be then expressed as follows:

$$
\bar{w}^{n a t}-\bar{w}^{i m}=\left(\bar{X}^{n a t}-\bar{X}^{i m}\right) \hat{\beta}+\left(\bar{\gamma}^{n a t}-\bar{\gamma}^{i m}\right) \eta+\left(\bar{\theta}^{n a t}-\bar{\theta}^{i m}\right) \sigma
$$

where superscripts nat and $i m$ correspond to native-born and immigrant workers, respectively.

Equation (3) quantifies the extent to which native-born/immigrant average wage differences are related to (a) differences in individual and job characteristics, (b) the influence of firm-related factors and (c) the influence of unobserved factors. More specifically, the first term on the right side of the equation corresponds to the portion of the wage differential attributable to the differences between the observed characteristics of the two groups $\left(\bar{X}^{\text {nat }}-\bar{X}^{\text {in }}\right)$, valued at market prices $(\hat{\beta})$. That is, this term of the decomposition coincides with the "explained" component of the standard Oaxaca-Blinder decomposition. ${ }^{8}$

The second term approximates the firm's influence on the wage differential. This term is taken as a product of the difference in the average standardised native-born/immigrant effect by firm $\left(\bar{\gamma}^{\text {nat }}-\bar{\gamma}^{i m}\right)$ and the dispersion of the sample-wide fixed-effects distribution $(\eta)$. According to it, the influence of firms on native-born/immigrant wage gaps depends on two factors. The first is to what extent native-born and immigrant workers work in firms where different wages are paid to observationally similar worker (i.e. if one group is segregated into low-wage firms). The significance of this phenomenon is captured by the difference in the two groups' average standardised effects by firm. The second is the magnitude of the wage-gap dispersion across firms, which determines the extent of the wage penalty of the group which is relatively more segregated into low-wage firms.

\footnotetext{
8 The widest possible range of observed characteristics has been chosen for use in the analysis. These comprise occupation, for which the different levels of endowments/distributions for native-born and immigrant workers may be affected by discriminatory practices and, as a result, they would not simply reflect competitive wage differentials. For that reason, the first term of the decomposition cannot be labelled 'non-discriminatory', as it frequently is in the literature.
} 
The third term measures the influence of unobserved factors (as unobserved ability, motivation and discrimination) on the relative wages of native-born and immigrant workers. As can be seen, this component is the product of, firstly, the difference in native-born/immigrant average wage residuals $\left(\bar{\theta}^{\text {nat }}-\bar{\theta}^{i m}\right)$ and, secondly, the dispersion of the sample-wide distribution of the wage residuals $(\sigma)$, which determines the specific wage penalty suffered by the group which is left comparatively disadvantaged by the unobserved factors.

As noted previously, the decomposition is based on the use of a pooled nativeborn/immigrant wage structure. Therefore, the third term in the decomposition implicitly captures the potential differences between the two groups' returns to their characteristics. Yet, it should be noted that although a usual interpretation in the literature of different wage returns to the observed characteristics between two groups is that they are indicative of discrimination, this interpretation is blurred in the context of this research, given that differences in immigrant wage returns relative to native-born workers can also be explained by the fact that the human capital acquired by immigrants in their home countries is not directly transferable to the Spanish labour market. For that reason, we consider that although the methodology used is not informative about whether differences exist between the returns to the two groups' characteristics this does not imply a major loss of information in the context of the empirical analysis.'

\subsection{Decomposition of wage distribution differences: the Jubn et al. (1993) methodology}

As stated earlier, the second part of the empirical analysis draws on a distributional approach in order to decompose differences in the entire wage distributions of immigrant and native-born workers. To do so, the technique put forward by Juhn et al. (1993) is used. This involves building hypothetical wages for each individual, then using the hypothetical wage distribution thus obtained to calculate distributional statistics, and finally decomposing the wage distribution differentials for the two groups according to the observed characteristics, the returns to the characteristics and the unobserved factors. Specifically, this technique begins with the separate estimation for native-born and immigrant workers of a wage function as follows:

$$
\begin{aligned}
& w_{i}^{n a t}=X_{i}^{n a t} \beta^{n a t}+\varepsilon_{i}^{n a t} \\
& w_{i}^{i m}=X_{i}^{i m} \beta^{i m}+\varepsilon_{i}^{i m}
\end{aligned}
$$

where, as before, superscripts nat and im correspond to native-born and immigrant workers, respectively. Thus, for example, $w_{i}^{\text {nat }}$ is the gross hourly wage for native-born worker $i$; $X_{i}^{\text {nat }}$ is a

\footnotetext{
9 On the other hand, estimating each group's wage returns separately would, in practice, make it impossible to quantify the effect of firm-specific segregation on immigrants' relative wages. This is because the estimation of fixed effects requires of each sampled company at least two observations for each group under consideration. In contrast, the EES sample does not include a very high number of observations for the different groups of immigrants.
} 
vector of the observed characteristics for the native-born group plus a constant term; $\beta^{\text {nat }}$ is the parameter vector estimated for that group; and $\varepsilon_{i}^{\text {nat }}$ is an individual random error term.

Following Juhn et al. (1993), the error term for an individual corresponds to the individual's position in the distribution of residuals. Thus, if $\theta_{i}=F\left(\varepsilon_{i} \mid X_{i}\right)$ is the percentile of the residual for worker $i$ with observed characteristics $X_{i}$, then by definition it can be expressed as $\varepsilon_{i}=F^{-1}\left(\theta_{i} \mid X_{i}\right)$, where $F^{-1}$ is the inverse of the cumulative distribution function. This means a residual in a different residual distribution, corresponding to percentile $\theta_{i}$, can be assigned to individual $i$.

Let us take as references a residual distribution $\bar{F}^{-1}$ (in our case, the average distribution for native-born and immigrant samples) and a wage structure $\bar{\beta}$ (the pooled wage structure estimated from the entire sample of native-born and immigrant workers). The hypothetical density functions for the two groups using fixed coefficients and a common residual distribution (thus restricting the wage distributions to vary among them only as a function of their characteristics) would then be expressed in the following way:

$$
\begin{aligned}
& w_{i}^{n a t 1}=X_{i}^{n a t} \bar{\beta}+\bar{F}^{-1}\left(\theta_{i} \mid X_{i}^{n a t}\right) \\
& w_{i}^{i m 1}=X_{i}^{i m} \bar{\beta}+\bar{F}^{-1}\left(\theta_{i} \mid X_{i}^{i m}\right)
\end{aligned}
$$

An alternative hypothetical distribution may, in turn, be simulated by maintaining only the effect of the unobserved factors fixed (thus restricting the wage distributions to vary among them as a function of both the coefficients and their characteristics). It can be expressed as follows:

$$
\begin{aligned}
& w_{i}^{\text {nat } 2}=X_{i}^{\text {nat }} \beta^{\text {nat }}+\bar{F}^{-1}\left(\theta_{i} \mid X_{i}^{\text {nat }}\right) \\
& w_{i}^{i m 2}=X_{i}^{i m} \beta^{i m}+\bar{F}^{-1}\left(\theta_{i} \mid X_{i}^{i m}\right)
\end{aligned}
$$

By using both hypothetical wage distributions, the differences in the nativeborn/immigrant actual wage distributions can be finally be decomposed into the contributions that stem from observed characteristics and prices, and unobserved factors. Thus, if $\Delta Y^{n}$ is the native-born/immigrant differential at a given point of the wage distribution (for example, at the mean, the median or a given percentile) or in a measure of disparity in the distribution (such as the standard deviation or the ratio between the 90th and 10th percentiles) in scenario $n$ (where 1 corresponds to both fixed coefficients and unobserved factors; 2 to fixed unobserved factors and the absence of superscript to the actual wage structures), the differential can be expressed as follows:

$$
\Delta Y=\Delta Y^{1}+\left(\Delta Y^{2}-\Delta Y^{1}\right)+\left(\Delta Y-\Delta Y^{2}\right)
$$

The first term on the right side of equation (10) measures the portion of the differential for characteristic $Y$ between native-born and immigrant actual wage distributions which can be 
attributed to the differences in the two groups' observed characteristics. The second term captures the portion explained by the differences in the returns to the characteristics. Finally, the third term corresponds to the disparities in the effect of the unobserved factors. ${ }^{10}$

\section{Empirical Results}

\subsection{Decomposition of the average wage differential}

Table 2 sets out descriptive information, obtained by estimating equation (1), regarding the decomposition results for the native-born/immigrant average wage gap (the gap is expressed as the difference between average pay levels for native-born and for immigrant workers). The first panel corresponds to the combined analysis for men and women. It can be seen that the average value of the standardised fixed effects by firm is slightly positive for native-born workers (0.005) and negative for immigrants as a whole (-0.137). This is coherent with a position in the distribution of effects by firm that is above the median for native-born workers (at the 54th percentile) ${ }^{11}$ and below for immigrants (at the 48th percentile). The result conclusively confirms that immigrants are, in general, segregated into low-wage firms. However, this is only the case for those immigrants from developing countries. On the whole, immigrants from developed countries work in firms that pay higher wages than those of native-born workers (the average effect by firm is 0.109 for this immigrant group and the corresponding percentile is the 57 th). In general, the described relative pattern is observed for both men and women in the disaggregated analysis by gender. Furthermore, keeping with the previous findings of Amuedo-Dorantes and De la Rica (2006) and Palacio and Simón (2006) for the Spanish labour market, women are seen to be systematically more segregated into low-wage firms relative to men in the same group. Nevertheless, whereas women from developed countries are relatively closer to men in the same group in terms of the distribution of fixed effects by firm (at the 57th and 58th percentiles, respectively), women from developing countries experience notably deeper segregation into lowwage firms (the average effect by firm is -0.399 for this group and the distribution percentile is the 37 th).

The fixed effects by firm have a standard deviation of 0.29 . This result reveals that the extent of wage differentiation between firms in the Spanish labour market is high from an international perspective (see Simón, 2005). It also implies the existence of a relatively severe penalty on the average wages of those groups segregated into low-wage firms.

The average wage residuals are slightly negative for native-born workers (-0.001) and positive for legal immigrants as a whole (0.022). However, this arises from the especially positive

\footnotetext{
10 Note that returns are assumed homogeneous in the extension of the Oaxaca-Blinder methodology, while differences in returns also account for a part of the wage differentials with the Juhn-Murphy-Pierce methodology, and that this can cause significant differences in the empirical results obtained with both techniques.

${ }^{11}$ As can be observed from these data, the median of the firm effects is lower than the median, which suggests that the distribution of firm effects is right-skewed.
} 
influence of the unobserved factors for immigrants from developed countries (whose average wage residual is located at the 64th percentile of the pooled distribution). By contrast, the legal immigrants from developing countries show a negative standardised residual (-0.035), which is nevertheless not much different from that of native-born workers. While the separate results for men largely coincide with the general case, a notable difference can be seen in the women's results. More specifically, the unobserved factors have a much greater beneficial effect on woman who are legal immigrants from developing countries than on native-born women (or, moreover, on men from the same immigrant group). These disparities by gender and place of origin may be due to differences in unobserved abilities. In turn, they may be related to self-selection processes that could vary by immigrant group, especially when account is taken that the microdata do not cover all segments of the labour market.

Panel A of Table 3 shows the results of the decomposition of the average wage differential for native-born and legal immigrant workers according to the three components on the right-hand side of equation (3). ${ }^{12}$ The average wage gap for legal immigrants from developing countries relative to the Spanish population, quantified at $0.256 \mathrm{log}$ points, is decomposed as follows: 0.184 points are explained by native-born workers having better endowments of observed characteristics; 0.008 points come from the unobserved factors; and an additional gap of 0.063 points stems from the segregation of immigrants in relatively low-wage firms. In addition, the detailed findings of the decomposition show that the characteristics which have a relatively greater negative effect on the relative wages of this group of immigrants are, in turn, their employment in low-wage occupations (having a net effect of 0.073 points); seniority (with a net effect of 0.059 points); lower educational attainment (0.039) and relatively less work with supervisory responsibilities (0.020). Notably, occupational and workplace segregation together account for 0.136 points of the wage gap. Actually, if occupational segregation of a vertical nature (captured by the control for fulfilment of supervisory tasks) is further added, total segregation accounts for 0.156 points, or $61 \%$ of the total. On the other hand, it is also noteworthy that the effect of the unobserved factors is almost negligible (0.008). This suggests that the wage gap between native-born and legal immigrant workers in the Spanish labour market is basically due to the differences in their individual characteristics and their job positions. Hence, once these factors are controlled for, no differentiated wage treatment is observed between native-born and legal immigrant workers from developing countries. ${ }^{13}$

\footnotetext{
${ }^{12}$ Detailed results of the wage equations used when calculating the decomposition are available from the authors upon request.

13 This result differs from the usual findings when carrying out wage comparisons for men and women in Spain using matched employer-employee microdata (Amuedo-Dorantes and De la Rica, 2006 and Palacio and Simón, 2006).
} 
As for immigrants from developed countries, their hourly wages are found to exceed those of native-born workers by $0.149 \log$ points. Of this differential, 0.069 points can be explained by better endowments of characteristics (despite having less seniority and potential experience); 0.049 come from the relatively positive influence of the unobserved factors and 0.031 stem from their higher presence in high-wage firms. In general, this group clearly tends to be employed in segments of the labour market that are relatively well-paid: firm and occupational segregation (both vertically and horizontally) together account for 81\% (0.121 in relation to 0.149 points) of its higher wage levels when compared to the native-born population.

The disaggregated results by gender show that male immigrants from developed countries benefit somewhat less from the effect of occupational and workplace segregation, while men from developing countries notably experience the most negative quantitative effect from the unobserved factors. In spite of this, the most marked differences with respect to the general case are found in the case of the women. When compared to the relevant native group, women from developed countries show a wage differential that is much greater than it is for men (the relative differential is $0.121 \log$ points greater). This is explained by their greater relative advantage in average educational attainment; their slighter relative disadvantage in average seniority and, above all, their greater presence in well-paying occupations and companies. On the other hand, women from developing countries show a lower wage differential than men in their group. This can be explained largely by the effect of the unobserved factors (and occurs in spite of their greater segregation in low-wage occupations and firms).

In summary, the evidence obtained to this point shows that segregation is one of the main causes for native-born/immigrant wage gaps. Furthermore, it suggests that segregation into both low-wage occupations and firms exerts a downward pressure on the wages of immigrants from developing countries, the group that suffers a significant wage disadvantage relative to native-born workers. Consequently, it is of great interest to analyse which are the types of firms where segregation of immigrants occurs. In order to do so, panel B of Table 3 sets out the results of the wage decomposition when the firms' fixed effects in equation (1) are replaced by firm attributes. These comprise region (17); sector (using Spain's National Classification of Economic Activity, CNAE-93); type of collective agreement (national, regional, company-specific or another type); size (five levels); the ratio of women and immigrants in the firm and the average years of education, seniority and potential experience of the firm's workforce.

It can be seen that legal immigrants, regardless of gender and country of origin, typically work more for small businesses and under sector-wide wage agreements, when compared to native-born workers. Such jobs have characteristics associated with low pay. On the other hand, legal immigrants are also found to a greater extent in regions and sectors with relatively higher pay. Moreover, since a greater number of immigrants, as expected, pushes down relative wages in 
firms, the segregation of immigrants in firms with a high proportion of immigrants is partially related to their relatively lower pay, regardless of gender and country of origin.

Nevertheless, the most influential effect of firm characteristics over the relative wages of legal immigrants comes, almost without exception, from the average education of the workforce. Thus, the evidence confirms that individual pay goes up with the mean educational level of the firm. For that reason, the presence of immigrants from developed countries in firms with relatively more educated workforces accounts for 0.022 points of their higher wages with respect to native-born workers (0.012 for men and 0.040 for women). In contrast, the tendency of immigrants from developing countries to work in firms with relatively less well-educated workforces explains 0.045 points of their wage disadvantage with respect to native-born workers (0.042 for men and 0.046 for women). Moreover, both groups of immigrants tend to work in firms with lower levels of potential experience and seniority, and that this is detrimental to their relative wage levels, as a consequence of the positive influence of these factors on individual pay.

Finally, it should be noted that the decomposition results of the native-born/immigrant wage gap obtained from the firm attributes are, in general, quite similar to the results obtained from the fixed effects by firm. Despite some nuances, this similarity is apparent both in the portion of the wage gap explained by the various individual and job characteristics and, also, in the quite similar contribution made by the set of attributes and the fixed effects by firm. In short, this result confirms that including a wide array of attributes for firms in the wage function permits to control relatively well for the influence of the firm on wage-setting, which is relevant inter alia since this is indeed the specification of the wage function used in the next stage of the empirical analysis.

\subsection{Decomposition of the wage structure differences}

As noted previously, the average wage differential between native-born and immigrants workers is representative of the aggregated behaviour of each of the two groups. However, the wage differential and its determinants could vary throughout the wage distribution. Other characteristics of the respective wage structures, such as the degree of dispersion, might also do so. For this reason, an analysis of the differences in the entire wage distributions is of interest as it would serve, among other things, to evaluate whether the main findings regarding the root cause of the average native-born/immigrant wage differential can be extended to the whole wage structure. What is more, the descriptive evidence confirms that the differences between the native-born and immigrant wage structures are not limited to average pay. This further supports the value of carrying out a distributional analysis.

With that aim, the technique put forward by Juhn et al. (1993), and described in detail in section 3, has been used. Basically, it consists of the construction of hypothetical wage distributions under a set of diverse assumptions. Then, the technique carries out a decomposition 
of the differences in the wage distribution for the two groups as a function of the contribution of their observed characteristics, the returns to the characteristics and the unobserved factors. On that account, this makes it possible to analyse what the wage structure for legal immigrants would be in the case they received a similar wage treatment than native-born workers and, alternatively, if the effect of the unobserved factors on the wages of both groups would be similar as well.

The first step involves the estimation of equations (4) and (5) with the same individual, job and firm characteristics set out previously as explanatory variables. Figures 2 and 3 show the kernel density functions estimated for the hypothetical wages for native-born and legal immigrant workers obtained from equations (6) to (9), based on the hypothesis that prices and unobserved factors are fixed (central panel) or that only unobserved factors are fixed (right-hand panel). For comparison purposes, the kernel density functions for the original wages are also shown (lefthand panel). In turn, Tables 4 and 5 show the decomposition findings for the relative contribution of the observed characteristics, the returns to the characteristics and the unobserved factors for native-born/immigrant differences at some representative points of their respective wage distributions (specifically, at the mean, the median and the 10th and 90th percentiles) and in the degree of dispersion (measured by standard deviation and the 90th/10th, 50th/10th and 90th/50th percentile ratios). The relative contribution of the observed characteristics is further broken down into the relative contributions of individual, job and firm characteristics. The purpose for this is to approximate the influence of occupational and firm segregation on the generation of differences in the wage distributions.

The direction of the native-born/immigrant wage differentials holds (with slight exceptions) throughout the wage distribution. However, as the distribution proceeds, they tend to widen significantly. Thus, the wage advantage systematically held by immigrants from developed countries relative to native-born workers is much less marked in the left tail of the distribution (0.042 points at the 10th percentile) than in the right tail (0.291 points at the 90th percentile). Similarly, the wage disadvantage faced by immigrants from developing countries is also much less marked in the lower segment of the distribution $(0.058$ points at the 10 th percentile) than in the higher part (0.548 at the 90th percentile). In the same vein, there are significant disparities in the degree of dispersion of the wage distributions for immigrant and native-born workers and, in turn, in the dispersion in the two tails of the respective distributions. Thus, the main reason for the relatively greater dispersion of the wage distribution for immigrants from developed countries lies in the higher degree of dispersion in the right tail of the distribution for men and in its left tail for women. By contrast, for immigrants from developing countries the wage structure is, irrespective of gender, comparatively less dispersed, primarily because of the more intense compression of wages in the left tail of the distribution. 
Comparing real and hypothetical wage structures for immigrants from developed countries and for native-born workers (Figure 2) shows that if wages for these two groups were equally affected by returns to the characteristics and by the unobserved factors (central panel), then their wage distributions would be more alike than they actually are (left-hand panel). Therefore, some portion of the difference in their wage structures must be due to the differentiated effect of the two sets of factors. This approximation is, in turn, more significant under the assumption of fixed returns and unobserved factors than it is under the alternative assumption of fixed unobserved factors alone (right-hand panel), pointing to the greater relative influence of returns on the disparity. In any case, even if the groups had equal returns to the characteristics and the same unobserved factors, their wage structures would not coincide. Rather, the relative differences in their characteristics would lead immigrants from developed countries to receive significantly higher relative average wages. To a lesser extent, they would also show a more dispersed wage distribution than native-born workers. The detailed findings for the decomposition of the differences in wage structures show that, irrespective of the point of reference in the wage distribution comparison, differences in characteristics are generally crucial in determining the wage advantage of immigrants from developed countries, very especially in the case of females (Table 4). However, these differences have less impact on the generation of the greater wage dispersion of immigrants (which results largely from the relative differences in the returns to the characteristics). Looking at the various types of characteristics, it can be seen that the relative impact of the differences in individual characteristics is not large. On the contrary, the differences in firm and, especially, job attributes play a much more relevant role in the shape of different wage structures. As regards this point, it must be emphasized that differences in job characteristics actually explain the bulk of the effect of differences in total characteristics in generating wage differentials between this group of immigrants and native-born workers. Job characteristics explain -0.068 points of the effect of -0.072 points at the median of the wage distribution of total characteristics; -0.126 against $-0,145$ points at the 90 th percentile and -0.034 against $-0,059$ points at the 10 th percentile. Likewise, they are also the origin of the major part of the impact of differences in characteristics in the disparities in the extent of wage dispersion. In short, this overall evidence suggests that firm and, in particular, occupational segregation are outstanding factors when explaining why immigrants from developed countries have higher wages throughout the distribution and a more dispersed wage distribution than native-born workers.

The wage structure for immigrants from developing countries would more closely resemble the wage structure for native-born workers (Figure 3), if their wages were equally affected by returns to the characteristics and by the unobserved factors. Nevertheless, quite substantial differences would persist, suggesting that differences in characteristics play a central 
role. This is confirmed by the decomposition findings, which show that, regardless of gender, this group's relative endowment of characteristics is the root cause both of their lower wage dispersion and of their lower relative wages throughout the wage structure (Table 5). In this regard, although the influence of differences in individual characteristics is not negligible, the differences in firm and, above all, job characteristics are the most relevant factors in the explanation of the differences in wage structures. Thus, as in the previous case, differences in job characteristics explain the bulk of the effect of differences in total characteristics in generating different wage structures between immigrants and native-born workers: job characteristics explain 0.089 points of the total effect of characteristics of 0.194 points at the median of the wage distribution; 0.248 against 0,443 points at the 90 th percentile; 0.075 against 0,107 points at the 10th percentile and 0.051 against 0.099 when considering differences in the standard deviation of wages.

To conclude, it must be stressed that additional enquiries reveal that although the breakdown of the impact of characteristics into the relative contributions of individual, job and firm characteristics changes slightly according to the order in which the variables are introduced, the various combinations nearly yield the same conclusions in practice for both groups of immigrants. Likewise, they show that the global effect of job attributes is always driven to a substantial extent by differences in occupational sorting (these overall results are available from the authors on request). Hence, the obtained empirical evidence conclusively confirms the key role played by firm and, particularly, occupational segregation in generating differences in the Spanish labour market between the wage distributions of native-born and legal immigrant workers.

\section{Conclusions}

This article has examined differences in the wage distributions between native-born and legal immigrants in the Spanish labour market, as well as the root cause of these differences. The analysis has been carried out on matched employer-employee microdata, and it has placed especial attention on the effects of immigrant segregation into low-wage occupations and firms. In doing so, it has drawn on the extensive literature that has analysed the part played by labour market segregation in the generation of racial and gender wage gaps. This literature, however, has not previously explored the impact on the relative wages of immigrants caused by workplace segregation.

In keeping with the general findings in the international migration literature, the Spanish case is characterised by wage distribution patterns for native-born and immigrant workers that differ quite significantly by place of origin: immigrants from developed countries, when compared with native-born workers, have higher average wages and show a wage distribution 
that is more dispersed, while immigrants from developing countries have lower average wages and show a relatively more compressed wage distribution. The use of several decomposition methodologies in order to decompose differences for native-born and immigrant workers in average wages and in the entire wage distribution has permitted to obtain extensive empirical evidence on the source of this phenomenon and, subsequently, analyse it thoroughly.

A major finding of the study is that the differences in the wage structures for native-born and legal immigrant workers are, to a great extent, accounted for by the differences in their observed characteristics. In this regard, of especial note is the impact of the segregation of immigrants in labour structures that are distinct from those of native-born workers. Although this segregation partially takes place through the sorting of immigrants across different firms than native-born workers, occupational segregation of immigrants seems to play a central role in generating differences in wage distributions.

The evidence obtained also suggests that those legal immigrants facing a considerable wage disadvantage relative to native-born workers (namely, those coming from developing countries) do not face a significantly different wage treatment when working in comparable jobs. From this result, it follows that any reduction in native-born/immigrant wage differences must be based on promotion and access to better jobs, given that anti-discrimination legislation may not be enough in this respect. At this point, it should be considered that labour market segregation of immigrants may well be arising from factors like imperfect transferability of human capital acquired before immigrating to Spain, but also be the result of discriminatory practices in the hiring process itself. While the analysis of the specific cause of this phenomenon lies beyond the scope of this study, it ought to be studied in future research. 


\section{References}

Abowd, J.M.; Kramarz, F. (1999): “The Analysis of Labor Markets Using Matched Employer-Employee Data”, in O. Ashenfelter and D. Card (ed.) Handbook of Labor Economics, ed. North-Holland.

Adsera, A.; Chiswick, B.R. (2007): "Are there gender and country of origin differences in immigrant labor market outcomes across European destinations?", Journal of Population Economics (forthcoming).

Alcalá, F.; Hernández, P.J. (2006): "Las externalidades del capital humano en la empresa española", Revista de Economía Aplicada, no 41 (vol. XIV), pp. 61-83.

Altonji, J.G., Blank, R.M. (1999): "Race and gender in the labor market", in O. Ashenfelter and D. Card (eds.), Handbook of Labor Economics, Vol. 3C, North-Holland, Amsterdam.

Amuedo-Dorantes, C.; De la Rica, S. (2006): "The Role of Segregation and Pay Structure on the Gender Wage Gap: Evidence from Matched Employer-Employee Data for Spain”, Contributions to Economic Analysis \& Policy, 5(1).

Amuedo-Dorantes, C.; De la Rica, S. (2007): "Labor Market Assimilation of Recents Immigrants in Spain", British Journal of Industrial Relations (forthcoming).

Baker, M.; Benjamin, D. (1994): "The Performance of Immigrants in the Canadian Labor Market", Journal of Labor Economics, vol. 12, no 3, pp. 369-405.

Battu, H.; Belfield C.R.; Sloane, P.J. (2003): "Human Capital Spill-Overs Within the Workplace", Oxford Bulletin of Economics and Statistics, 65 (5), pp. 575-594.

Bauer, T.; Zimmermann, K. (1999): “Occupational Mobility of Ethnic Migrants“, IZA DP 774.

Bayard, K.; Hellerstein, J.; Neumark, D.; Troske, K. (1999): "Why are racial and ethnic wage gaps larger for men than for women? Exploring the role of segregation using the new worker-establishment characteristics database", en J.C. Haltiwanger et al. (eds.), The Creation and Analysis of Employer-Employee Matched Data, ed. Elsevier.

Bayard, K.; Hellerstein, J.; Neumark, D.; Troske, K. (2003): "New evidence on sex segregation and sex differences in wages from matched employee-employer data", Journal of Labor Economics, vol. 21, $\mathrm{n}^{\circ} 4$, pp. 887-922.

Becker, G. (1957): The Economics of Discrimination, ed. University of Chicago Press.

Blau, F.D.; Kahn, L.M. (1997): "Swimming Upstream: Trends in the Gender Wage Differential in the 1980s", Journal of Labor Economics, vol. 15, $\mathrm{n}^{\circ}$ 1, pp. 1-42.

Blinder, A.S. (1973): "Wage Discrimination: Reduced Form and Structural Estimates", Journal of Human Resources, no 8, pp. 436-455.

Borjas, G. J. (1987): "Self-Selection and Earnings of Immigrants", American Economic Review, 77(4), pp. 531553.

Borjas, G. J. (1994): “The Economics of Immigration”, Journal of Economic Literature, 32, pp. 1667-1717.

Borjas G. J. (1999): "The Economic Analysis of Immigration", in Ashenfelter O. and Card D. (eds.) Handbook of Labor Economics, vol. 3A, ed. North-Holland.

Butcher, K.; DiNardo, J. (2002): “The Immigrant and Native-born Wage Distributions: Evidence from United States Censuses", Industrial and Labor Relations Review, 56(1), pp. 96-121.

Card, D. (2004): "Is the New Immigration Really so Bad?", IZA DP 1119.

Chiswick, R.B. (1978): "The Effect of Americanization on the Earnings of Foreign-born Men", Journal of Political Economy, 86(5), pp. 81-87.

Chiswick, R.B.; Lee, Y.; Miller, P. (2005a): "Immigrant Earnings: A Longitudinal Analysis", Revien of Income and Wealth, 51(84), pp. 485-503.

Chiswick, R.B.; Lee, Y.; Miller, P. (2005b): "Longitudinal Analysis of Immigrant Occupational Mobility: A Test of the Immigrant Assimilation Hypothesis", International Migration Review, 39(2), pp. 332-353.

Consejo Económico y Social (2004): La inmigración y el mercado de trabajo en España, Informe 2/2004.

Constant, A.; Massey, D. (2003): "Labor Market Segmentation and the Earnings of German Guestworkers“, IZA DP 774.

Davia, M.A.; Hernanz, V. (2004): “Temporary Work and Segmentation in the Spanish Labour Market: An Empirical Analysis through the Study of Wage Differentials", Spanish Economic Review, volume 6, number 4, pp. 291-318.

De la Rica, S. (2004): "Wage gaps between workers with indefinite and fixed-term contracts: The impact of firm and occupational segregation", Moneda y Crédito, vol. 219, pp. 43-69.

Friedberg, R. M. (2000): "You can't take it with you? Immigrant assimilation and the portability of human capital”, Journal of Labour Economics, 18(2), pp. 221-251.

Gardeazábal, J.; Ugidos, A. (2004): "More on identification in detailed wage decompositions", The Review of Economics and Statistics, 86(4), pp. 1034-1036. 
Gartner, H.; Stephan, G. (2004): "How collective contracts and Works councils reduce the gender wage gap", IAB Discussion paper 7/2004.

Haltiwanger, J.C., Lane, J., Spletzer, J.R., Theeuwes, J.J.; Troske, K. (1999): The Creation and Analysis of EmployerEmployee Matched Data, ed. Elsevier.

Hellerstein, J.; Neumark, D. (2005): "Workplace segregation in the United States: Race, ethnicity and skill", NBER working paper 11599.

Hirsch, B.; Macpherson, D. (2004): "Wages, Sorting on Skill, and the Racial Composition of Jobs", Journal of Labor Economics, vol. 22, no 1, pp. 189-210.

Izquierdo, M.; Jimeno, J.F. (2005): "Inmigración: desarrollos recientes y consecuencias económicas", Boletin Económico del Banco de España, febrero, pp. 41-49.

Jasso, G.; Rosenzweig, M.R. (1988): "How Well Do U.S. Immigrants Do?: Vintage Effects, Emigration Selectivity, and Occupational Mobility", in P. Schultz (ed.) Research in Population Economics. Volume 6, ed. JAI Press.

Juhn, C., Murphy, K.; Pierce, B. (1993): "Wage inequality and the rise in returns to skill”, Journal of Political Economy 101, 31, pp. 410-442.

Lalonde, R.J.; Topel, R.H. (1997): "The economic impact of international migration and the economic performance of migrants", in Rosenzweig and Stark (eds.) Handbook in population and family economics, ed. Elsevier Science.

Lam, K.C. ; Liu, P.W. (2002) : "Earnings divergence of immigrants", Journal of Labor Economics, 20, pp. 86101.

Liu, P.W.; Zhang, J.; Chong, S. (2004) : “Occupational segregation and wage differentials between natives and immigrants: evidence from Hong Kong", Journal of Development Economics, 73, pp. 395-413.

Neumark, D. (1988): "Employer's discriminatory behaviour and the estimation of wage discrimination", Journal of Human Resources, 23, pp. 279-295.

Oaxaca, R. (1973): "Male-Female Wage Differentials in Urban labor Markets", International Economic Review Vol.14, No.3, pp.139-148.

Oaxaca, R.; Ramson, M. (1994): "On discrimination and the decomposition of wage differentials", Journal of Econometrics, 61, pp. 5-22.

Oaxaca, R.; Ramson, M. (1999): "Identification in detailed wage decompositions", The Review of Economics and Statistics, 81(1), pp. 154-157.

Pagán, R. (2007): "Diferencias salariales entre el empleo a tiempo completo y tiempo parcial", Revista de Economia Aplicada (forthcoming).

Palacio, J.I.; Simón, H. (2006): "Segregación laboral y diferencias salariales por razón de sexo en España", Estadística Española, Vol. 48, n 183 , pp. 493-524.

Phelps, E. (1972). “The Statistical Theory of Racism and Sexism”, American Economic Review, 62(4), pp. 659661.

Simón, H. (2005): “Employer Wage Differentials from an International Perspective”, Economics Letters, Vol. 88(2).

Simón, H.; Ramos, R.; Sanromá, E. (2007): "Segregación laboral y estructuras salariales de nativos e inmigrantes en España. Un análisis con datos emparejados empresa-trabajador", Documento de Trabajo IVIE, WP-EC 2007-03.

Weiss, Y.; Sauer, R.M.; Gotlibovski, M. (2003): "Immigration, Search and Loss of Skill”, Journal of Labor Economics, 21(3), pp. 557-591.

Wilkins, R. (2003): "Immigrant and Native-Born Earnings Distributions in Australia: 1982-1996", Australian Journal of Labour Economics, 6(1), pp. 83-115.

Yuengert, A.M. (1994): "Immigrant Earnings, Relative to What? The Importance of Earnings Function Specification and Comparison Points", Journal of Applied Econometrics, vol. 9, n 1, pp. 71-90. 


\section{Figures and tables}

Figure 1

Kernel density functions of the logarithm of hourly wages of natives and immigrants.

a) Men and women

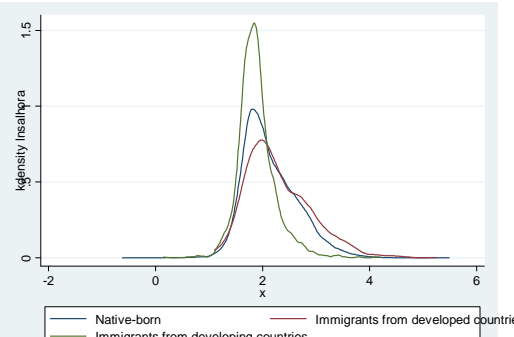

b) Men

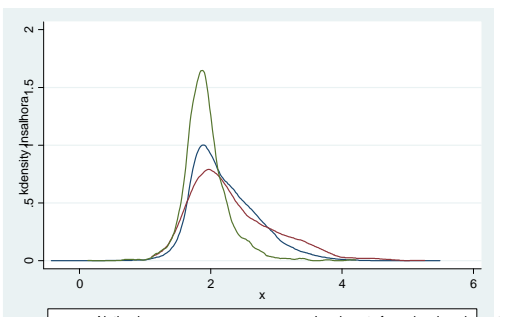

c) Women

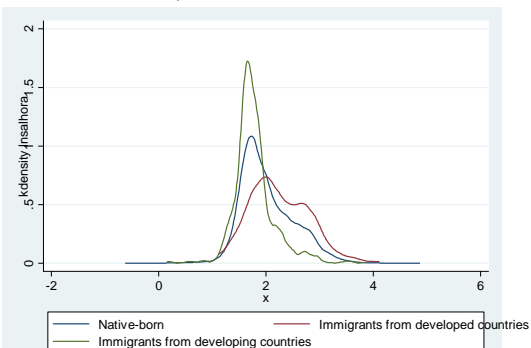

Figure 2

Kernel density functions of the logarithm of hourly wages of natives and immigrants (left) and the hypothetical logarithm of hourly wages under the hypothesis of fixed prices and unobservable factors (centre) and fixed unobservable factors (right). Developed countries' immigrants.

a) Men and women
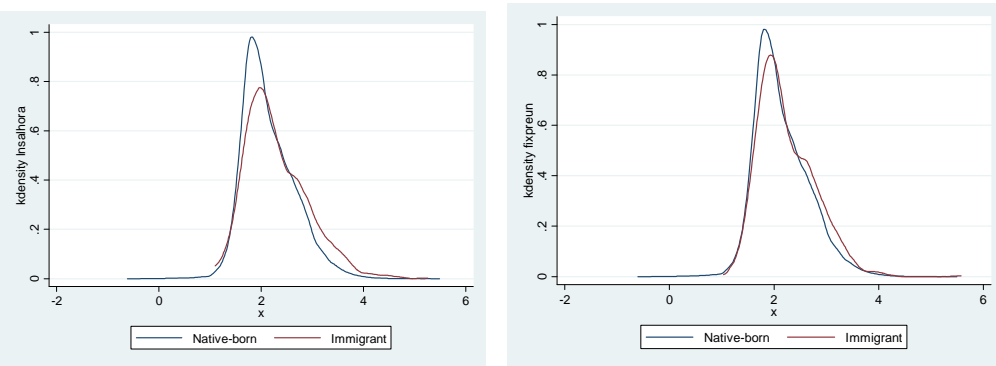

b) Men
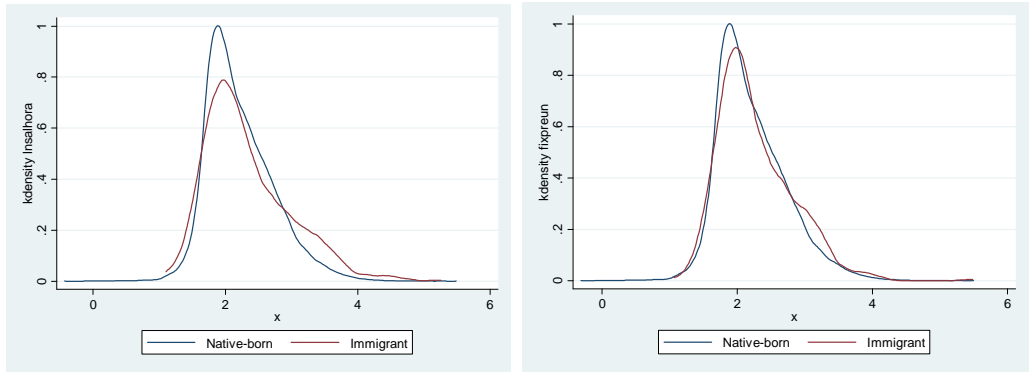

c) Women

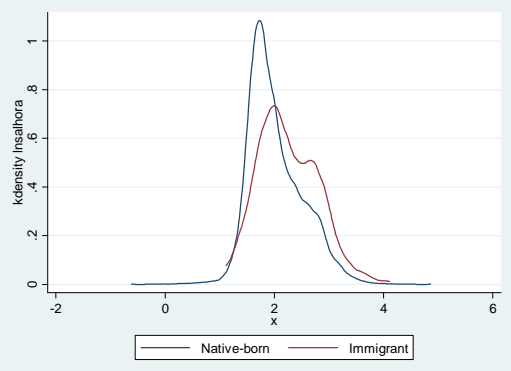

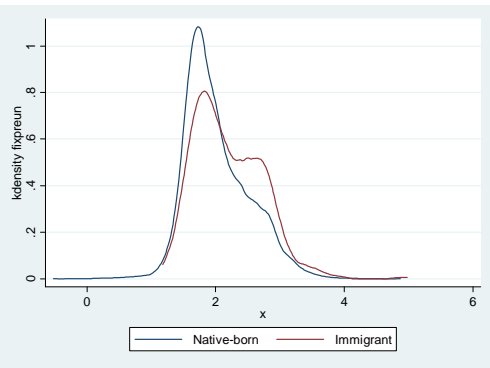
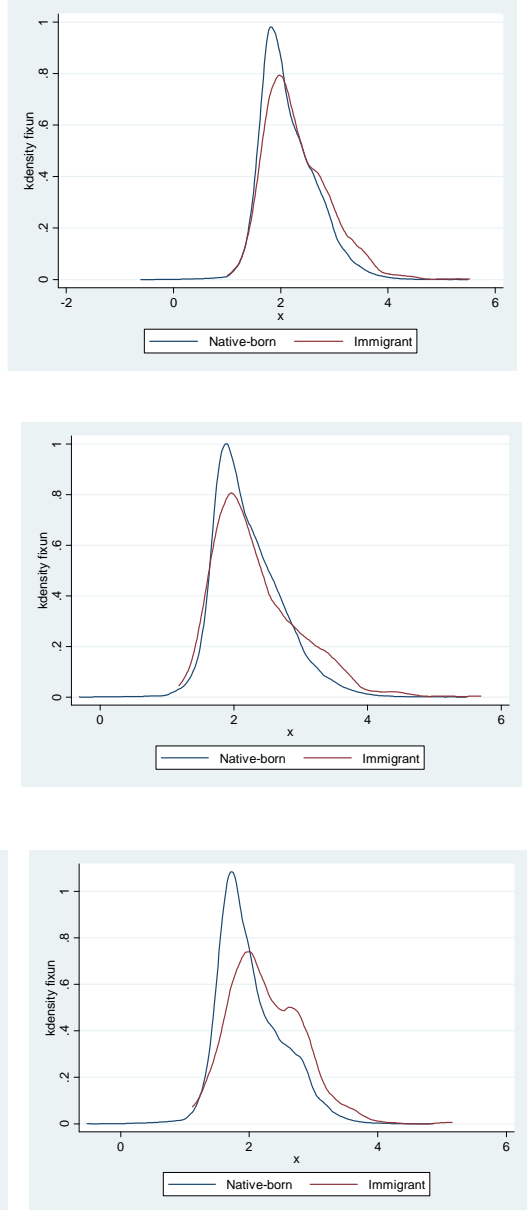

Note: Reference prices are the ones estimated for the pool of natives and immigrants. The unobservable factors reference is the average of the unobservable factors of natives and immigrants in separate estimates for each group. 
Figure 3

Kernel density function of the logarithm of hourly wages of natives and immigrants (left) and the hypothetical logarithm of hourly wages under the hypothesis of fixed prices and unobservable factors (centre) and fixed unobservable factors (right). Developing countries' immigrants.

$$
\text { a) Men and women }
$$
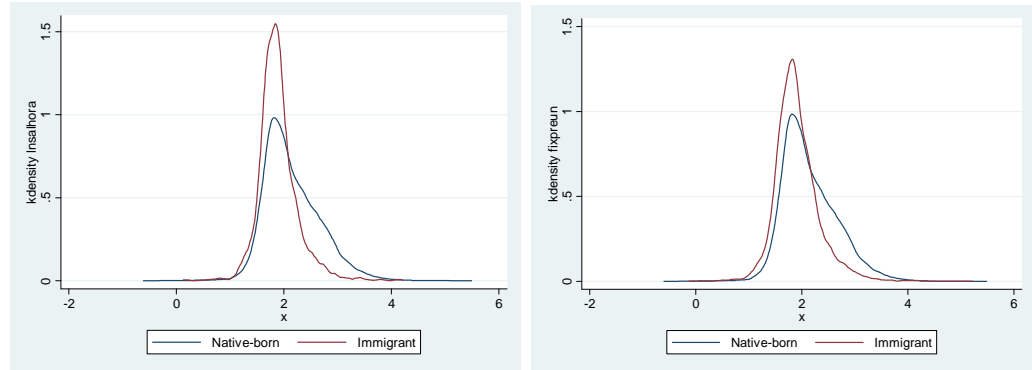

b) Men
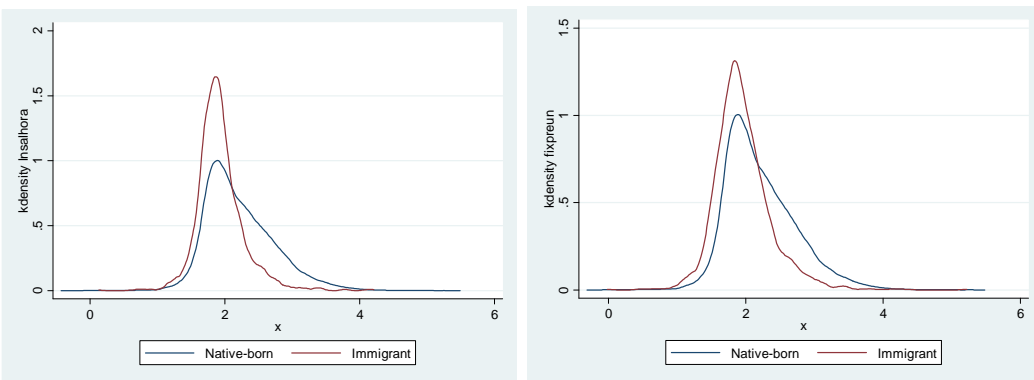

c) Women
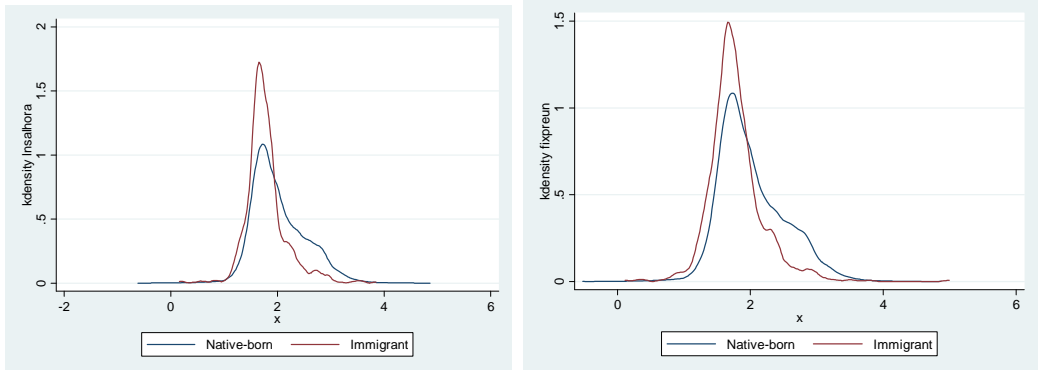
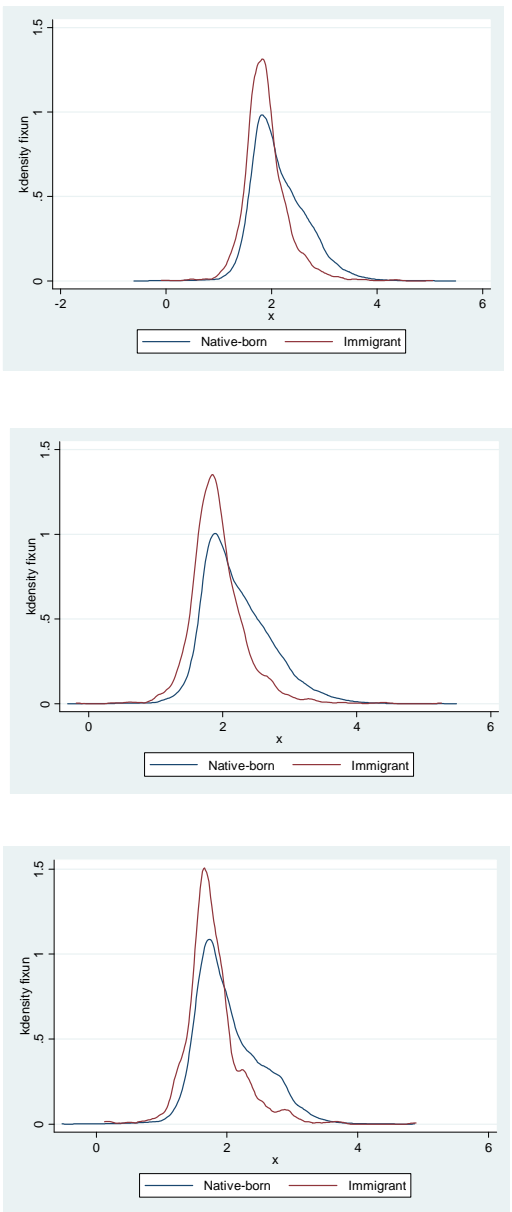

Note: Reference prices are the ones estimated for the pool of natives and immigrants. The unobservable factors reference is the average of the unobservable factors of natives and immigrants in separate estimates for each group. 
Table 1

Average wages and wage dispersion of natives and immigrants.

\begin{tabular}{|c|c|c|c|c|}
\hline & Natives & Immigrants & $\begin{array}{l}\text { Developed } \\
\text { countries' } \\
\text { immigrants }\end{array}$ & $\begin{array}{l}\text { Developing } \\
\text { countries' } \\
\text { immigrants }\end{array}$ \\
\hline \multicolumn{5}{|l|}{ A) Men and women } \\
\hline \multicolumn{5}{|l|}{ Average wage } \\
\hline Hourly wage (euros) & 9.93 & 8.39 & 12.44 & 7.16 \\
\hline Logarithm of the hourly wage & 2.145 & 1.985 & 2.294 & 1.889 \\
\hline \multicolumn{5}{|l|}{ Hourly wage dispersion } \\
\hline Variance of the logarithm & 0.716 & 0.682 & 0.782 & 0.601 \\
\hline Coefficient of variation & 0.694 & 0.850 & 0.970 & 0.546 \\
\hline Gini index & 0.306 & 0.288 & 0.376 & 0.209 \\
\hline Theil index & 0.171 & 0.191 & 0.275 & 0.096 \\
\hline \multicolumn{5}{|l|}{ B) $M e n$} \\
\hline \multicolumn{5}{|l|}{ Average wage } \\
\hline Hourly wage (euros) & 10.65 & 8.63 & 13.23 & 7.411 \\
\hline Logarithm of the hourly wage & 2.217 & 2.012 & 2.322 & 1.930 \\
\hline \multicolumn{5}{|l|}{ Hourly wage dispersion } \\
\hline Variance of the logarithm & 0.712 & 0.675 & 0.802 & 0.589 \\
\hline Coefficient of variation & 0.701 & 0.896 & 1.064 & 0.540 \\
\hline Gini index & 0.305 & 0.284 & 0.402 & 0.201 \\
\hline Theil index & 0.172 & 0.199 & 0.320 & 0.092 \\
\hline \multicolumn{5}{|l|}{ C) Women } \\
\hline \multicolumn{5}{|l|}{ Average wage } \\
\hline Hourly wage (euros) & 8.66 & 7.84 & 11.11 & 6.46 \\
\hline Logarithm of the hourly wage & 2.020 & 1.919 & 2.246 & 1.781 \\
\hline \multicolumn{5}{|l|}{ Hourly wage dispersion } \\
\hline Variance of the logarithm & 0.706 & 0.695 & 0.741 & 0.614 \\
\hline Coefficient of variation & 0.637 & 0.691 & 0.661 & 0.550 \\
\hline Gini index & 0.296 & 0.292 & 0.317 & 0.217 \\
\hline Theil index & 0.155 & 0.166 & 0.172 & 0.103 \\
\hline
\end{tabular}

Table 2

Wage differential between natives and immigrants and descriptive evidence of the decomposition of differences in average wages.

\begin{tabular}{|c|c|c|c|c|}
\hline & Natives & Immigrants & $\begin{array}{c}\text { Developed } \\
\text { countries' } \\
\text { immigrants }\end{array}$ & $\begin{array}{l}\text { Developing } \\
\text { countries' } \\
\text { immigrants }\end{array}$ \\
\hline \multicolumn{5}{|l|}{ A) Men and women } \\
\hline Wage differential between natives and immigrants & - & 0.160 & -0.149 & 0.256 \\
\hline Average firm fixed effect & 0.005 & -0.137 & 0.109 & -0.213 \\
\hline Percentile in the distribution of firm fixed effects & 54 & 48 & 57 & 45 \\
\hline Standard deviation of firm fixed effects & 0.290 & 0.290 & 0.290 & 0.290 \\
\hline Average wage residual & -0.001 & 0.022 & 0.206 & -0.035 \\
\hline Percentile in the distribution of wage residuals & 51 & 53 & 64 & 49 \\
\hline \multicolumn{4}{|l|}{ B) Men } & 0.236 \\
\hline Wage differential between natives and immigrants & - & 0.205 & -0.105 & 0.287 \\
\hline Average firm fixed effect & 0.066 & -0.090 & 0.116 & -0.145 \\
\hline Percentile in the distribution of firm fixed effects & 56 & 50 & 58 & 48 \\
\hline Standard deviation of firm fixed effects & 0.290 & 0.290 & 0.290 & 0.290 \\
\hline Average wage residual & 0.001 & -0.023 & 0.220 & -0.087 \\
\hline Percentile in the distribution of wage residuals & 51 & 50 & 64 & 46 \\
\hline Standard deviation of wage residuals & 0.236 & 0.236 & 0.236 & 0.236 \\
\hline \multicolumn{5}{|l|}{ C) Women } \\
\hline Wage differential between natives and immigrants & - & 0.101 & -0.226 & 0.239 \\
\hline Average firm fixed effect & -0.102 & -0.251 & 0.095 & -0.399 \\
\hline Percentile in the distribution of firm fixed effects & 49 & 43 & 57 & 37 \\
\hline Standard deviation of firm fixed effects & 0.290 & 0.290 & 0.290 & 0.290 \\
\hline Average wage residual & -0.036 & 0.130 & 0.182 & 0.108 \\
\hline Percentile in the distribution of wage residuals & 49 & 59 & 62 & 58 \\
\hline Standard deviation of wage residuals & 0.236 & 0.236 & 0.236 & 0.236 \\
\hline
\end{tabular}


Table 3

Decomposition of the differential of average wages between natives and immigrants.

\begin{tabular}{|c|c|c|c|c|c|c|}
\hline & \multicolumn{2}{|c|}{ Men and women } & \multicolumn{2}{|c|}{ Men } & \multicolumn{2}{|c|}{ Women } \\
\hline & $\begin{array}{l}\text { Developed } \\
\text { countries' } \\
\text { immigrants }\end{array}$ & $\begin{array}{l}\text { Developing } \\
\text { countries' } \\
\text { immigrants }\end{array}$ & $\begin{array}{l}\text { Developed } \\
\text { countries' } \\
\text { immigrants }\end{array}$ & $\begin{array}{l}\text { Developing } \\
\text { countries' } \\
\text { immigrants }\end{array}$ & $\begin{array}{l}\text { Developed } \\
\text { countries' } \\
\text { immigrants }\end{array}$ & $\begin{array}{l}\text { Developing } \\
\text { countries' } \\
\text { immigrants }\end{array}$ \\
\hline $\begin{array}{l}\text { Wage differential among natives and immigrants } \\
\text { A }\end{array}$ & -0.149 & 0.256 & -0.105 & 0.287 & -0.226 & 0.239 \\
\hline Characteristics(1) & $-0.069(46.3)$ & $0.184(71.9)$ & $-0.039(37.1)$ & $0.205(71.4)$ & $-0.124(54.9)$ & $0.178(74.5)$ \\
\hline Gender & 0.001 & -0.011 & 0.000 & 0.000 & 0.000 & 0.000 \\
\hline Educational attainment & -0.029 & 0.034 & -0.022 & 0.032 & -0.041 & 0.033 \\
\hline Experience & 0.010 & -0.003 & 0.009 & 0.000 & 0.011 & -0.006 \\
\hline Seniority & 0.035 & 0.059 & 0.042 & 0.064 & 0.025 & 0.050 \\
\hline Type of contract/Full-time or part-time & 0.004 & 0.012 & 0.004 & 0.014 & 0.003 & 0.006 \\
\hline Occupation & -0.079 & 0.073 & -0.061 & 0.071 & -0.110 & 0.081 \\
\hline Supervision tasks & -0.011 & 0.020 & -0.011 & 0.024 & -0.012 & 0.014 \\
\hline Wage residuals (2) & $-0.049(32.9)$ & $0.008(3.1)$ & $-0.052(49.6)$ & $0.021(7.3)$ & $-0.044(19.5)$ & $-0.026(10.9)$ \\
\hline Firm fixed effects (3) & $-0.031(20.8)$ & $0.063(24.6)$ & $-0.015(14.3)$ & $0.061(21.3)$ & $-0.058(25.6)$ & $0.087(36.4)$ \\
\hline $\mathrm{B}$ & & & & & & \\
\hline Characteristics (1) & $-0.084(56.4)$ & $0.238(93.0)$ & $-0.039(37.1)$ & $0.259(90.2)$ & $-0.163(72.1)$ & $0.248(103.8)$ \\
\hline Gender & 0.001 & -0.011 & 0.000 & 0.000 & 0.000 & 0.000 \\
\hline Educational attainment & -0.030 & 0.022 & -0.024 & 0.019 & -0.040 & 0.023 \\
\hline Experience & 0.010 & -0.004 & 0.008 & -0.002 & 0.011 & -0.007 \\
\hline Seniority & 0.035 & 0.058 & 0.041 & 0.063 & 0.025 & 0.050 \\
\hline Type of contract/Full-time or part-time & 0.003 & 0.012 & 0.004 & 0.013 & 0.003 & 0.006 \\
\hline Occupation & -0.082 & 0.092 & -0.063 & 0.092 & -0.116 & 0.098 \\
\hline Supervision tasks & -0.009 & 0.016 & -0.009 & 0.018 & -0.009 & 0.011 \\
\hline Region & -0.010 & -0.015 & -0.013 & -0.015 & -0.006 & -0.014 \\
\hline Activity sector & -0.008 & -0.006 & -0.004 & -0.002 & -0.015 & -0.004 \\
\hline Collective agreement & 0.005 & 0.009 & 0.006 & 0.008 & 0.004 & 0.010 \\
\hline Firm size & 0.005 & 0.017 & 0.002 & 0.014 & 0.010 & 0.019 \\
\hline Women's proportion in the firm & 0.004 & -0.007 & 0.008 & -0.005 & -0.003 & 0.003 \\
\hline Immigrant's proportion in the firm & 0.006 & 0.006 & 0.006 & 0.006 & 0.006 & 0.005 \\
\hline Average education years in the firm's workforce & -0.022 & 0.045 & -0.012 & 0.042 & -0.040 & 0.046 \\
\hline Average seniority years in the firm's workforce & 0.002 & 0.004 & 0.003 & 0.004 & 0.001 & 0.003 \\
\hline Average experience years in the firm's workforce & 0.006 & 0.002 & 0.006 & 0.003 & 0.005 & 0.000 \\
\hline Wage residuals (2) & $-0.065(43.6)$ & $0.018(7.0)$ & $-0.066(62.9)$ & $0.028(9.8)$ & $-0.063(27.9)$ & $-0.010(-3.8)$ \\
\hline Firm fixed effects (3) & - & - & - & - & - & - \\
\hline
\end{tabular}


Table 4

Decomposition of the differences in the wage structure of natives and immigrants. Developed countries' immigrants.

\begin{tabular}{|c|c|c|c|c|c|c|c|}
\hline & \multirow{2}{*}{$\begin{array}{l}\text { Differential } \\
\text { between } \\
\text { natives and } \\
\text { immigrants } \\
(1)+(2)+(3)\end{array}$} & \multirow[b]{2}{*}{ Returns (1) } & \multirow[b]{2}{*}{$\begin{array}{l}\text { Unobservable } \\
\text { factors (2) }\end{array}$} & \multicolumn{4}{|c|}{$\begin{array}{l}\text { Contribution to the differential } \\
\qquad \text { Characteristics }\end{array}$} \\
\hline & & & & $\begin{array}{c}\text { Total } \\
\text { (3) }\end{array}$ & $\begin{array}{c}\text { Individual } \\
\text { characteristics }\end{array}$ & $\begin{array}{c}\text { Job } \\
\text { characteristics }\end{array}$ & $\begin{array}{c}\text { Firm } \\
\text { characteristics }\end{array}$ \\
\hline \multicolumn{8}{|l|}{ A) Men and women } \\
\hline Average & -0.149 & -0.062 & 0.003 & -0.090 & 0.012 & -0.087 & -0.015 \\
\hline Median & -0.132 & -0.067 & 0.007 & -0.072 & 0.022 & -0.068 & -0.027 \\
\hline 10th percentile & -0.042 & -0.002 & 0.019 & -0.059 & -0.002 & -0.034 & -0.024 \\
\hline 90th percentile & -0.291 & -0.128 & -0.018 & -0.145 & 0.008 & -0.126 & -0.027 \\
\hline 90 th/10th percentile ratio & -0.248 & -0.126 & -0.037 & -0.085 & 0.010 & -0.092 & -0.003 \\
\hline 50 th/10th percentile ratio & -0.090 & -0.065 & -0.012 & -0.012 & 0.024 & -0.034 & -0.003 \\
\hline 90 th/50th percentile ratio & -0.159 & -0.061 & -0.024 & -0.073 & -0.014 & -0.058 & 0.000 \\
\hline \multicolumn{8}{|l|}{ B) $M e n$} \\
\hline Average & -0.105 & -0.060 & 0.005 & -0.050 & 0.019 & -0.067 & -0.002 \\
\hline Median & -0.062 & -0.042 & 0.000 & -0.020 & 0.040 & -0.052 & -0.007 \\
\hline 10th percentile & 0.016 & -0.004 & 0.014 & 0.006 & 0.007 & -0.031 & 0.029 \\
\hline 90th percentile & -0.354 & -0.207 & -0.002 & -0.145 & 0.011 & -0.127 & -0.029 \\
\hline 90 th/10th percentile ratio & -0.370 & -0.204 & -0.016 & -0.150 & 0.004 & -0.096 & -0.058 \\
\hline 50 th/10th percentile ratio & -0.077 & -0.038 & -0.014 & -0.025 & 0.032 & -0.021 & -0.036 \\
\hline 90 th/50th percentile ratio & -0.292 & -0.166 & -0.002 & -0.125 & -0.028 & -0.074 & -0.022 \\
\hline \multicolumn{8}{|l|}{ C) Women } \\
\hline Average & -0.226 & -0.060 & 0.007 & -0.173 & -0.005 & -0.127 & -0.041 \\
\hline Median & -0.265 & -0.064 & -0.014 & -0.186 & 0.000 & -0.129 & -0.057 \\
\hline 10th percentile & -0.079 & 0.008 & 0.018 & -0.105 & 0.003 & -0.066 & -0.041 \\
\hline 90th percentile & -0.201 & -0.104 & 0.026 & -0.123 & -0.005 & -0.127 & 0.009 \\
\hline 90 th/10th percentile ratio & -0.122 & -0.111 & 0.008 & -0.019 & -0.008 & -0.061 & 0.050 \\
\hline 50 th $/ 10$ th percentile ratio & -0.186 & -0.072 & -0.032 & -0.082 & -0.004 & -0.062 & -0.016 \\
\hline 90 th/50th percentile ratio & 0.064 & -0.039 & 0.040 & 0.063 & -0.004 & 0.002 & 0.066 \\
\hline Standard deviation & -0.050 & -0.042 & 0.020 & -0.028 & -0.009 & -0.030 & 0.011 \\
\hline
\end{tabular}

Note: The differential between natives and immigrants in a particular characteristic of the wage structure is defined as the value of the characteristic for natives minus the corresponding value for the immigrants.

Table 5

Decomposition of the differences in the wage structure of natives and immigrants. Developing countries' immigrants.

\begin{tabular}{|c|c|c|c|c|c|c|c|}
\hline & \multirow{2}{*}{$\begin{array}{c}\text { Differential } \\
\text { between } \\
\text { natives and } \\
\text { immigrants } \\
(1)+(2)+(3)\end{array}$} & \multirow[b]{2}{*}{ Returns (1) } & \multirow[b]{2}{*}{$\begin{array}{l}\text { Unobservable } \\
\text { factors (2) }\end{array}$} & \multicolumn{4}{|c|}{$\begin{array}{l}\text { Contribution to the differential } \\
\qquad \text { Characteristics }\end{array}$} \\
\hline & & & & $\begin{array}{c}\text { Total } \\
(3)\end{array}$ & $\begin{array}{c}\text { Individual } \\
\text { characteristics }\end{array}$ & $\begin{array}{c}\text { Job } \\
\text { characteristics }\end{array}$ & $\begin{array}{c}\text { Firm } \\
\text { characteristics }\end{array}$ \\
\hline \multicolumn{8}{|l|}{ A) Men and women } \\
\hline Average & 0.256 & 0.017 & 0.001 & 0.238 & 0.063 & 0.119 & 0.056 \\
\hline Median & 0.195 & 0.012 & -0.012 & 0.194 & 0.057 & 0.089 & 0.048 \\
\hline 10th percentile & 0.058 & 0.019 & -0.068 & 0.107 & 0.033 & 0.075 & -0.001 \\
\hline 90th percentile & 0.548 & 0.036 & 0.069 & 0.443 & 0.086 & 0.248 & 0.109 \\
\hline 90 th $/ 10$ th percentile ratio & 0.490 & 0.017 & 0.137 & 0.336 & 0.053 & 0.173 & 0.110 \\
\hline 50 th $/ 10$ th percentile ratio & 0.137 & -0.007 & 0.056 & 0.087 & 0.024 & 0.015 & 0.048 \\
\hline 90 th/50th percentile ratio & 0.353 & 0.023 & 0.081 & 0.249 & 0.029 & 0.158 & 0.061 \\
\hline \multicolumn{8}{|l|}{ B) $M e n$} \\
\hline Average & 0.287 & 0.026 & 0.001 & 0.260 & 0.082 & 0.123 & 0.055 \\
\hline Median & 0.236 & 0.022 & -0.003 & 0.216 & 0.072 & 0.096 & 0.049 \\
\hline 10th percentile & 0.095 & 0.013 & -0.070 & 0.152 & 0.067 & 0.070 & 0.015 \\
\hline 90th percentile & 0.574 & 0.039 & 0.072 & 0.463 & 0.110 & 0.238 & 0.115 \\
\hline 90 th $/ 10$ th percentile ratio & 0.479 & 0.026 & 0.142 & 0.311 & 0.044 & 0.167 & 0.100 \\
\hline 50 th $/ 10$ th percentile ratio & 0.141 & 0.009 & 0.067 & 0.065 & 0.006 & 0.025 & 0.034 \\
\hline 90 th/50th percentile ratio & 0.338 & 0.017 & 0.075 & 0.247 & 0.038 & 0.142 & 0.066 \\
\hline \multicolumn{8}{|l|}{ C) Women } \\
\hline Average & 0.239 & -0.002 & 0.003 & 0.238 & 0.056 & 0.116 & 0.066 \\
\hline Median & 0.191 & 0.000 & -0.001 & 0.192 & 0.054 & 0.076 & 0.062 \\
\hline 10th percentile & 0.083 & 0.014 & -0.049 & 0.118 & 0.044 & 0.066 & 0.008 \\
\hline 90th percentile & 0.502 & -0.027 & 0.053 & 0.476 & 0.077 & 0.255 & 0.144 \\
\hline 90 th $/ 10$ th percentile ratio & 0.419 & -0.041 & 0.102 & 0.358 & 0.033 & 0.189 & 0.136 \\
\hline 50th/10th percentile ratio & 0.107 & -0.013 & 0.047 & 0.073 & 0.010 & 0.010 & 0.053 \\
\hline 90 th $/ 50$ th percentile ratio & 0.311 & -0.028 & 0.054 & 0.285 & 0.023 & 0.179 & 0.083 \\
\hline Standard deviation & 0.122 & -0.019 & 0.048 & 0.093 & 0.008 & 0.045 & 0.040 \\
\hline
\end{tabular}

Note: The differential between natives and immigrants in a particular characteristic of the wage structure is defined as the value of the characteristic for natives minus the corresponding value for the immigrants. 


\section{Appendix}

Table A.1

Average values of the variables and detailed results from the regression (continues).

Natives $\quad$ Immigrants $\quad$ Developing countries' immigrantsDeveloped countries' immigrants Coefficient

Men and women Men WomenMen and women Men Women Men and women Men Women Men and women Men Women Estimation with Estimation with

\begin{tabular}{|c|c|c|c|c|c|c|c|c|c|c|c|c|c|c|}
\hline$\overline{M e n}$ & 0.638 & 1.000 & 0.000 & 0.707 & 1.000 & 0.000 & 0.731 & 1.000 & 0.000 & 0.630 & 1.000 & 0.000 & $0.058^{* *}$ & $0.061^{* *}$ \\
\hline Women & 0.362 & 0.000 & 1.000 & 0.293 & 0.000 & 1.000 & 0.269 & 0.000 & 1.000 & 0.370 & 0.000 & 1.000 & $-0.058 * *$ & $-0.061 * *$ \\
\hline Incomplete primary education & 0.012 & 0.013 & 0.011 & 0.061 & 0.073 & 0.032 & 0.077 & 0.088 & 0.046 & 0.009 & 0.014 & 0.000 & $-0.151 * *$ & $-0.104 * *$ \\
\hline Primary education & 0.258 & 0.284 & 0.212 & 0.446 & 0.481 & 0.360 & 0.503 & 0.523 & 0.449 & 0.260 & 0.325 & 0.149 & $-0.118^{* *}$ & $0.000^{* *}$ \\
\hline Secondary education (first stage) & 0.296 & 0.319 & 0.256 & 0.233 & 0.242 & 0.212 & 0.252 & 0.252 & 0.251 & 0.172 & 0.203 & 0.119 & $-0.103 * *$ & $-0.110^{* *}$ \\
\hline Secondary education (second stage) & 0.098 & 0.093 & 0.106 & 0.076 & 0.065 & 0.101 & 0.064 & 0.057 & 0.084 & 0.113 & 0.096 & 0.144 & $-0.032 * *$ & $-0.037 * *$ \\
\hline Occupational education (first degree) & 0.070 & 0.059 & 0.091 & 0.027 & 0.020 & 0.043 & 0.024 & 0.017 & 0.045 & 0.034 & 0.032 & 0.038 & $-0.073 * *$ & $-0.074 * *$ \\
\hline Occupational education (second degree) & 0.083 & 0.086 & 0.078 & 0.028 & 0.027 & 0.030 & 0.023 & 0.022 & 0.025 & 0.045 & 0.048 & 0.041 & $-0.036 * *$ & $-0.037 * *$ \\
\hline Bachelor & 0.082 & 0.060 & 0.119 & 0.040 & 0.020 & 0.089 & 0.017 & 0.011 & 0.033 & 0.117 & 0.056 & 0.222 & $0.021 * *$ & $0.023 * *$ \\
\hline Graduate & 0.099 & 0.085 & 0.124 & 0.087 & 0.069 & 0.130 & 0.040 & 0.031 & 0.066 & 0.239 & 0.215 & 0.279 & $0.075^{* *}$ & $0.074 * *$ \\
\hline Post-graduate & 0.001 & 0.001 & 0.001 & 0.001 & 0.001 & 0.001 & 0.000 & 0.000 & 0.001 & 0.004 & 0.006 & 0.000 & $0.206 * *$ & $0.206 * *$ \\
\hline Doctor & 0.002 & 0.002 & 0.002 & 0.002 & 0.001 & 0.002 & 0.000 & 0.000 & 0.000 & 0.006 & 0.005 & 0.008 & $0.211 * *$ & $0.140^{* *}$ \\
\hline Seniority & 7.271 & 7.888 & 6.187 & 1.425 & 1.323 & 1.672 & 0.890 & 0.863 & 0.966 & 3.165 & 3.059 & 3.344 & $0.012 * *$ & $0.013^{* *}$ \\
\hline Seniority*Seniority & 137.64 & 156.01 & 105.32 & 13.88 & 12.38 & 17.49 & 6.31 & 5.61 & 8.19 & 38.51 & 37.93 & 39.49 & $0.000^{* *}$ & $0.000^{* *}$ \\
\hline Fixed-term contract & 0.264 & 0.259 & 0.273 & 0.555 & 0.587 & 0.479 & 0.609 & 0.638 & 0.532 & 0.379 & 0.392 & 0.355 & $-0.019 * *$ & $-0.018^{* *}$ \\
\hline Not fixed-term contract & 0.736 & 0.741 & 0.727 & 0.445 & 0.413 & 0.521 & 0.391 & 0.362 & 0.468 & 0.621 & 0.608 & 0.645 & $0.019^{* *}$ & $0.018^{* *}$ \\
\hline Part-time work & 0.105 & 0.041 & 0.218 & 0.123 & 0.055 & 0.286 & 0.122 & 0.052 & 0.314 & 0.126 & 0.070 & 0.220 & 0.019 ** & $0.014 * *$ \\
\hline Full-time work & 0.895 & 0.959 & 0.782 & 0.877 & 0.945 & 0.714 & 0.878 & 0.948 & 0.686 & 0.874 & 0.930 & 0.780 & $-0.019 * *$ & $-0.014^{* *}$ \\
\hline Experience & 21.649 & 22.715 & 19.773 & 19.732 & 20.2041 & 18.593 & 19.916 & 20.247 & 19.018 & 19.135 & 20.045 & 17.588 & $0.014^{* *}$ & $0.015^{* *}$ \\
\hline Experience*experience & 608.17 & 656.57 & 523.05 & 474.49 & 490.064 & 436.95 & 472.30 & 483.62 & 441.61 & 481.62 & 514.41 & 425.91 & $0.000^{* *}$ & $0.000^{* *}$ \\
\hline Supervision tasks & 0.259 & 0.291 & 0.204 & 0.169 & 0.174 & 0.158 & 0.116 & 0.121 & 0.103 & 0.340 & 0.372 & 0.287 & $0.070 * *$ & $0.055 * *$ \\
\hline No supervision tasks & 0.741 & 0.709 & 0.796 & 0.831 & 0.826 & 0.842 & 0.884 & 0.879 & 0.897 & 0.660 & 0.628 & 0.713 & $-0.070^{* *}$ & $-0.055^{* *}$ \\
\hline Andalucía & 0.097 & 0.100 & 0.092 & 0.036 & 0.033 & 0.045 & 0.030 & 0.027 & 0.037 & 0.057 & 0.053 & 0.065 & - & $0.038^{* *}$ \\
\hline Aragón & 0.046 & 0.049 & 0.042 & 0.060 & 0.066 & 0.047 & 0.069 & 0.073 & 0.057 & 0.033 & 0.040 & 0.022 & - & $0.052^{* *}$ \\
\hline Asturias & 0.034 & 0.036 & 0.031 & 0.012 & 0.011 & 0.014 & 0.009 & 0.008 & 0.014 & 0.019 & 0.022 & 0.014 & - & $-0.015^{* *}$ \\
\hline Baleares & 0.031 & 0.031 & 0.032 & 0.061 & 0.058 & 0.068 & 0.056 & 0.057 & 0.053 & 0.078 & 0.062 & 0.106 & - & $0.031 * *$ \\
\hline Canarias & 0.043 & 0.044 & 0.042 & 0.077 & 0.072 & 0.090 & 0.060 & 0.065 & 0.048 & 0.133 & 0.099 & 0.190 & - & $-0.032 * *$ \\
\hline Cantabria & 0.018 & 0.019 & 0.017 & 0.010 & 0.011 & 0.006 & 0.010 & 0.011 & 0.009 & 0.007 & 0.011 & 0.000 & - & $-0.026 * *$ \\
\hline Castilla y León & 0.045 & 0.047 & 0.042 & 0.033 & 0.036 & 0.024 & 0.039 & 0.043 & 0.030 & 0.010 & 0.010 & 0.011 & - & $-0.039 * *$ \\
\hline Castilla-La Mancha & 0.052 & 0.055 & 0.047 & 0.032 & 0.037 & 0.021 & 0.030 & 0.033 & 0.022 & 0.038 & 0.049 & 0.019 & - & $-0.031 * *$ \\
\hline Cataluña & 0.163 & 0.151 & 0.184 & 0.222 & 0.226 & 0.212 & 0.224 & 0.223 & 0.225 & 0.217 & 0.238 & 0.182 & - & $0.088 * *$ \\
\hline Comunidad Valenciana & 0.107 & 0.113 & 0.098 & 0.096 & 0.096 & 0.095 & 0.103 & 0.104 & 0.100 & 0.071 & 0.064 & 0.084 & - & 0.000 \\
\hline Extremadura & 0.025 & 0.026 & 0.024 & 0.005 & 0.004 & 0.007 & 0.004 & 0.002 & 0.008 & 0.010 & 0.013 & 0.005 & - & $-0.126 * *$ \\
\hline Galicia & 0.064 & 0.065 & 0.062 & 0.019 & 0.019 & 0.019 & 0.011 & 0.010 & 0.014 & 0.045 & 0.054 & 0.030 & - & $-0.077 * *$ \\
\hline Madrid & 0.132 & 0.117 & 0.158 & 0.196 & 0.176 & 0.245 & 0.208 & 0.186 & 0.267 & 0.158 & 0.137 & 0.192 & - & $0.036 * *$ \\
\hline Murcia & 0.038 & 0.039 & 0.035 & 0.036 & 0.042 & 0.020 & 0.043 & 0.048 & 0.027 & 0.014 & 0.021 & 0.003 & - & $-0.056^{* *}$ \\
\hline Navarra & 0.026 & 0.026 & 0.025 & 0.053 & 0.055 & 0.048 & 0.052 & 0.052 & 0.053 & 0.055 & 0.067 & 0.035 & - & $0.065^{* *}$ \\
\hline País Vasco & 0.058 & 0.062 & 0.052 & 0.024 & 0.024 & 0.023 & 0.018 & 0.019 & 0.016 & 0.043 & 0.046 & 0.038 & - & $0.059 * *$ \\
\hline La Rioja & 0.018 & 0.019 & 0.016 & 0.027 & 0.031 & 0.017 & 0.031 & 0.035 & 0.022 & 0.011 & 0.014 & 0.005 & - & $0.024 * *$ \\
\hline Ceuta y Melilla & 0.001 & 0.001 & 0.001 & 0.002 & 0.003 & 0.000 & 0.003 & 0.004 & 0.000 & 0.000 & 0.000 & 0.000 & - & $0.009 * *$ \\
\hline
\end{tabular}


Table A.1

Average values of the variables and detailed results from the regression (continuation).

$\begin{array}{lll}\text { Natives } & \text { Immigrants } & \text { Developing countries' immigrantsDeveloped countries' immigrants }\end{array}$

Coefficient

Men and women Men WomenMen and women Men Women Men and women Men Women Men and women Men Women Estimation with Estimation with

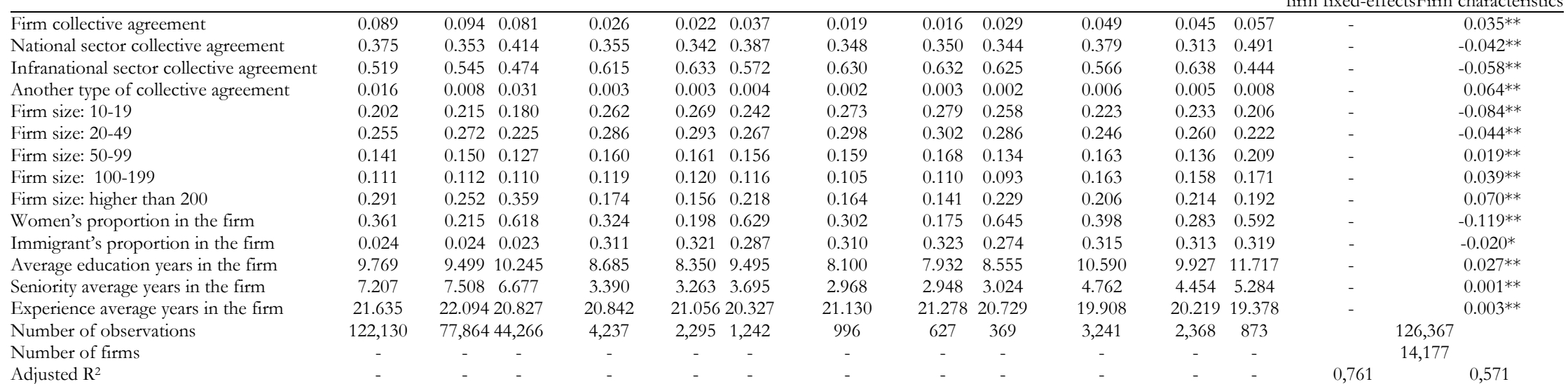

Adjusted $\mathrm{R}^{2}$

Note: The specification of the wage equation has also included job controls and, in the model with firm characteristics, activity sector controls. ${ }^{* *}$ and $*$ indicate that the estimated coefficient is significantly different from zero at the $1 \%$ and $5 \%$ levels, respectively. 